\title{
EXPLORING THE IMPACT OF NATIONAL CULTURE ON LOGISTICS PERFORMANCE
}

\author{
A Thesis \\ presented to \\ the Faculty of California Polytechnic State University, \\ San Luis Obispo
}

\author{
In Partial Fulfillment \\ of the Requirements for the Degree \\ Master of Science in Industrial Engineering
}

by

Deepak Parathur Kesavan

March 2019 
(C) 2019

Deepak Parathur Kesavan

ALL RIGHTS RESERVED 
COMMITTEE MEMBERSHIP

TITLE: Exploring the Impact of National Culture on Logistics Performance

AUTHOR: Deepak Parathur Kesavan

DATE SUBMITTED: $\quad$ March 2019

COMMITTEE CHAIR: Ahmed Deif, Ph.D.

Assistant Professor of Industrial Technology

COMMITTEE MEMBER: Tali Freed, Ph.D.

Professor of Industrial and Manufacturing

Engineering

COMMITTEE MEMBER: Jose Macedo, Ph.D.

Professor of Industrial and Manufacturing

Engineering 


\section{ABSTRACT \\ Exploring the Impact of National Culture on Logistics Performance \\ Deepak Parathur Kesavan}

The increased logistics complexity due to supply chain globalization requires a deeper understanding of a country's logistics performance. This performance is usually captured through infrastructure, services and procedure elements and understood in operational and economical terms. This thesis adds a social view to understand logistics performance variation across countries through focusing on their national culture dimensions. Using secondary data from the international Logistics Performance Index (LPI) report as well as the scores from Hofstede's national culture dimension surveys, the impact of national culture on logistics performance was explored. Statistical results showed Power Distance and Uncertainty Avoidance dimensions were found to have a negative correlation with the LPI while Individualism as well as Long Term Orientation were both positively correlated to the LPI. This cultural understanding adds to the growing social literature research on logistics performance and can guide logistics managers in their decisions regarding where and when to locate their resources.

Keywords: Logistics, national culture, performance, Hofstede 


\section{ACKNOWLEDGMENTS}

This thesis would not have been possible without the help of several people. First and foremost, I would like to thank my advisor Dr. Deif. It was his ideas and encouragement that helped immensely during this process. As a lost international student, he was a guide, a mentor and also a friend. He was always available to give advice and feedback, while being understanding about the limited time available to students. I will always fondly remember the time spent in his office coming up the new ideas and ways to improve the quality of the research. His help with the grammar and general flow and outline of the thesis was instrumental in me being able to complete it on time. Secondly, I would like to thank Dr Freed. She was always welcoming and had a smile on her face whenever we spoke. Her help in all matters in and out of this thesis such as class selection, independent study, future plans, etc. all helped me devote more time to the thesis and to complete it on time. I would also like to thank Dr Pouragabagher and Dr Macedo for all their help in statistics and their classes. I had the opportunity to work as a grader for both of them and it helped me refine my statistics knowledge and help with my thesis, while simultaneously allowing me to earn some money. I would love to thank each of the Calpoly staff by name, but there would be far too many to do that. I learned a lot of new things from a whole lot of amazing people, that I will never forget for the rest of my life. Calpoly and all the people I met along the way will always have a special place in my heart. Most importantly, I would have to thank my family. Without their hard work, sacrifice and support, I would not be where I am today. I would also like to thank all of my friends and teachers in India as well for always being available to talk, irrespective of the time and location. 


\section{TABLE OF CONTENTS}

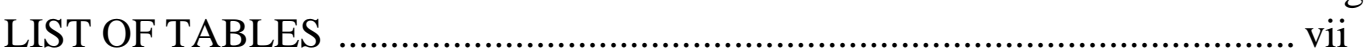

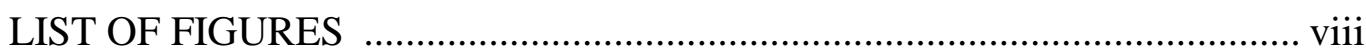

CHAPTER

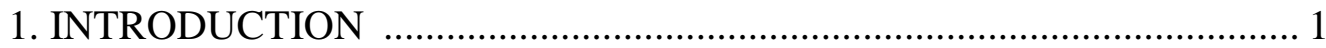

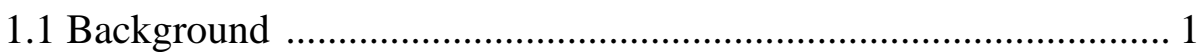

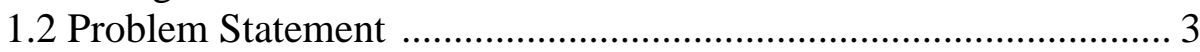

1.3 Research methodology .............................................................. 5

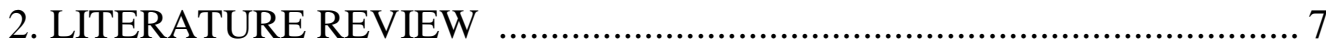

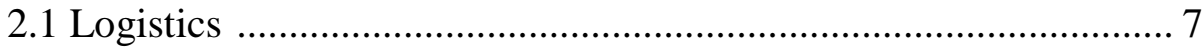

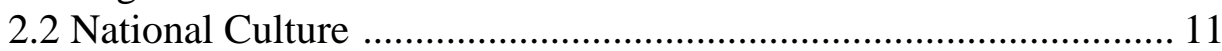

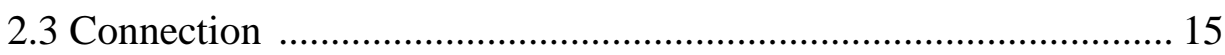

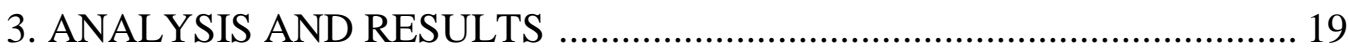

3.1 Data Gathering and Information ................................................ 19

3.2 Hypotheses ........................................................................... 19

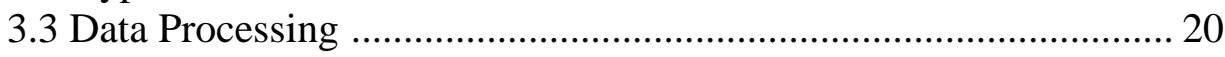

3.4 Statistical Tests and Results ........................................................ 21

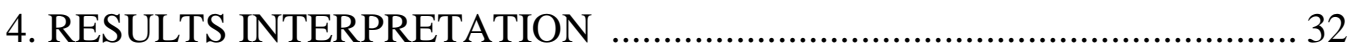

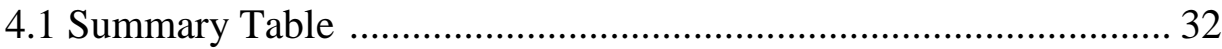

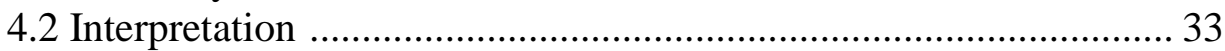

4.2.1 Power Distance ...................................................................... 33

4.2.2 Uncertainty Avoidance ..................................................... 34

4.2.3 Long Term Orientation ………………………................. 36

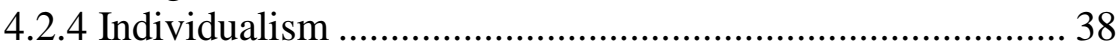

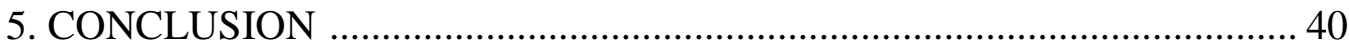

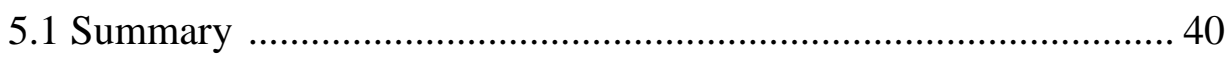

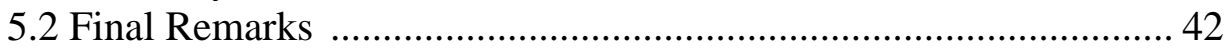

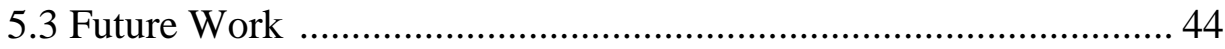

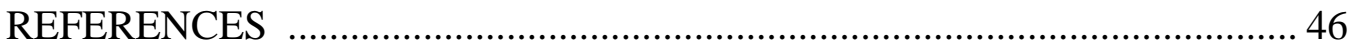

APPENDICES

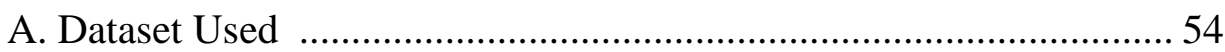

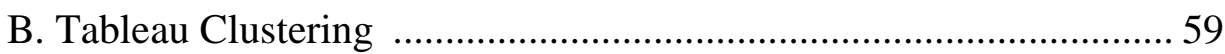

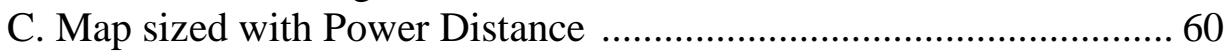

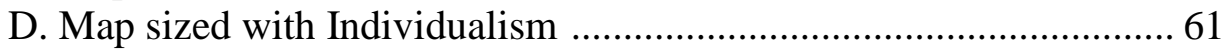

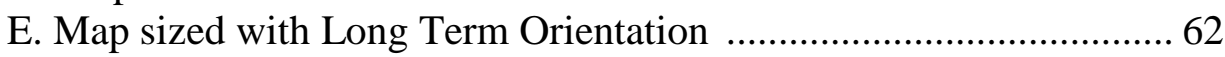

F. Map sized with Uncertainty Avoidance ………………………….... 63 


\section{LIST OF TABLES}

Table

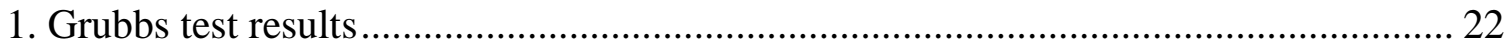

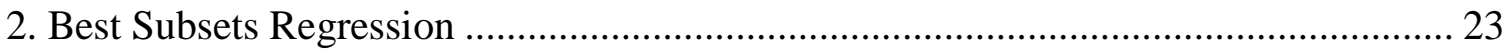

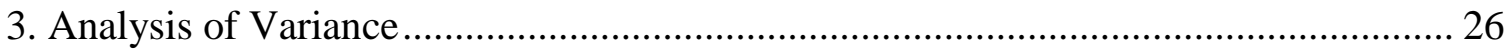

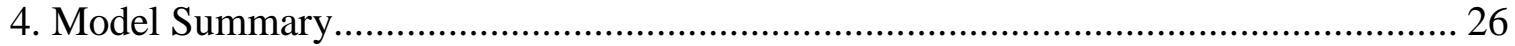

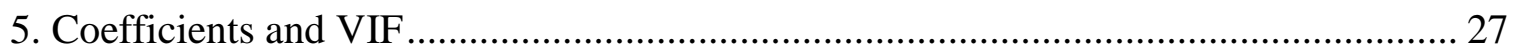

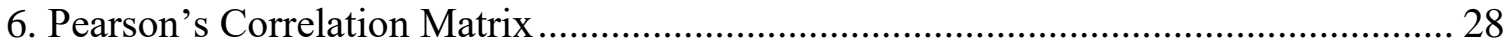

7. Pearson's Correlation Results Summary ….............................................................. 32

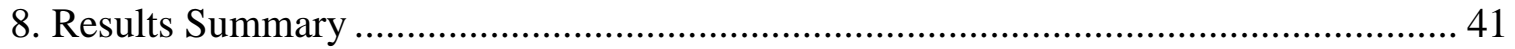




\section{LIST OF FIGURES}

$\begin{array}{lll}\text { Figure } & \text { Page }\end{array}$

1. LPI overperformers and underperformers (LPI report 2018) ..................................... 17

2. Assumptions of Regression.................................................................................... 25

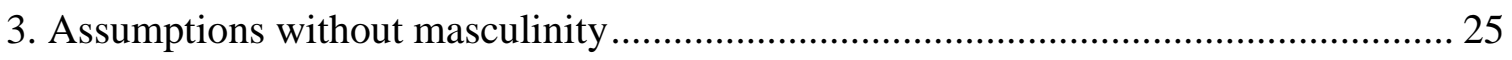

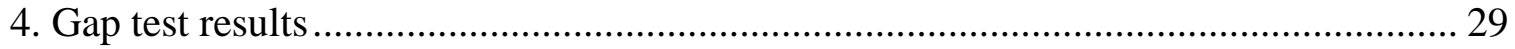

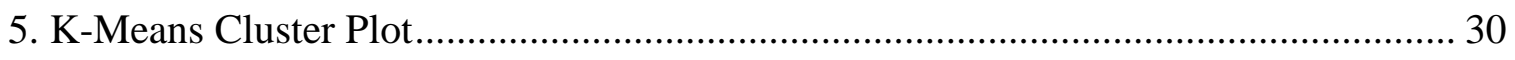

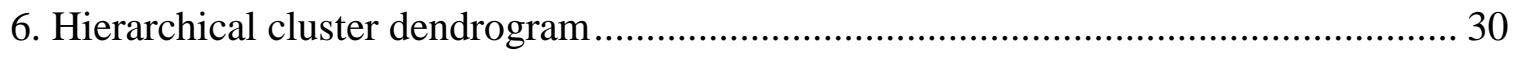

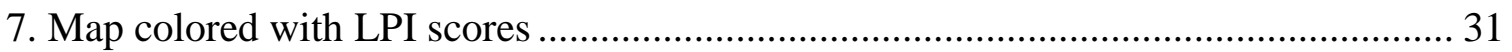




\section{Chapter 1-INTRODUCTION}

\subsection{Background}

The Council of Supply Chain Management Professionals (2007) defines logistics management as "that part of Supply Chain Management that plans, implements, and controls the efficient, effective forward and reverse flow and storage of goods, services and related information between the point of origin and the point of consumption in order to meet customers' requirements." Therefore, logistics consists of all activities involved in each step of the supply chain and forms an integral part of this system. Capturing and understanding logistics performance dimensions have been of interest to logistics researchers and practitioners. The logistics literature is full of different attempts to model and empirically test logistics performance. Among these attempts, is the Logistics Performance Index (LPI), developed and measured by the International Trade Department of The World Bank. The dataset and report that is considered for the LPI portion of this thesis is from the work by (Arvis et al., 2018). The LPI report has been prepared from 2007 to 2018 six times and is still being updated biennially. According to the same report, the LPI score is based on six major categories, i.e. Customs, Infrastructure, International shipments, Logistics quality and competence, Tracking and tracing and Timeliness. These components are further discussed in the literature review section. The LPI consists of both domestic and global scores and ranks for countries as well. The LPI survey is given to logistics professionals and they are asked to rate up to eight preselected countries across the six components listed above, based on how easy or difficult it is to conduct business with those countries. In 2018, the survey consisted of 6000 responses across 160 countries globally and 100 countries domestically. The LPI 
scores are constructed by using a principal component analysis. The inputs to this are the average scores of the country on all the above dimensions. This is normalized, and the output is the LPI score, which is a weighted average designed to maximize the percentage variation in the original six indicators (Arvis et al., 2018).

The term culture can be defined by Hofstede as a collective programming of the mind, which differentiates members of one group or category from another (Hofstede, 2011). Therefore, culture is not something that a person is born with. Culture is created by the environment in which the individual grows up in and influences the way an individual functions in society. There are many types of culture, for instance, organizational culture, national culture, economic culture, etcetera. This thesis focuses on national culture, as the LPI consists of scores for several countries. It is important to understand the different types of culture as each type is unique. Organizational culture, for example, is the culture that is present in the mindset of employees in an organization. This organization may have locations in multiple countries, but the mindset or culture of all its employees are expected to be similar. Thus, each country can have several organizations with multiple organizational cultures which can be defined across different cultural frameworks; however, each country is only expected to have a single national culture. There are many reasons for the differences in national culture around the world. Some of the major reasons have been attributed to religion, linguistics, geographical location, etcetera. Hofstede is a Dutch psychologist and is widely considered as an expert on national culture. This thesis uses Hofstede's model as the basis of its research as it is the most widely accepted model. The other models and the reasoning behind selecting the Hofstede model are discussed in the literature review section of this thesis. Hofstede 
created his dimensions from IBM employees in over 50 countries and this consisted of 112,000 questionnaires. His results were validated when he administered the same questions to 400 trainee employees belonging to 30 countries and obtained the same results as his initial analysis. He used an ecological factor analysis on this data and obtained four major dimensions. Further research by Hofstede, with the help of the Chinese culture connection and Minkov led to the discovery of the Long/Short Term Orientation and the Indulgence/Restraint dimensions. According to Hofstede, national culture can be defined across six dimensions: Power Distance, Uncertainty Avoidance, Individualism/Collectivism, Masculinity/Femininity, Long/Short Term Orientation, and Indulgence/Restraint. Each of these dimensions is defined and explored in the results section of this thesis, except for the Indulgence/Restraint dimension and the Masculinity/Femininity dimension. The reasoning behind these omissions is discussed in section 4.1.

\subsection{Problem Statement}

With the increasing awareness of the economic role of logistics and the growing interest in the benefits of leveraging logistics to increase customer value, measuring the performance of logistics has become a high priority (Griffis et al. 2007). This performance has a direct impact on each country's economy, as well as its differentiation in the global logistics market. This market includes all activities involved in logistics and is estimated to have a turnover of over US\$ 4.3 trillion (Arvis et al., 2018). According to (Waters, 2003, pp.19), "Without logistics, no materials move, no operations can be done, no products are delivered, and no customers are served." Thus, logistics performance is an important factor to be considered for any country. Logistics affects several areas other 
than the economy as well. Some of these include general connectivity, investment by stakeholders, political policies, etcetera. Research by (Martí, Puertas, \& García, 2014) has shown that the LPI is an important factor to be considered for the flow of trade in developing countries. Research has also indicated that a single point increase in the LPI score could cause an increase in trade by $16 \%$ before accounting for relative price effects. Thus, it is essential for countries to try and improve their logistics performance. Furthermore, the logistics community is also interested in studying external and internal aspects and relationships that affect each country's logistics performance like national GDP, innovation level, talent management among other factors. The work by (Fawcett \& Cooper, 1998) highlights the importance of measuring logistics performance and has shown that the procedure to measure logistics performance is constantly evolving.

National culture has been found to affect areas of operations management, as well as supply chain and marketing. National culture and the Hofstede model in particular have also been applied to a very wide variety of fields and situations and the majority of these are discussed in greater detail in the literature review section of this thesis. The Hofstede model has been cited over 55,000 times on Google scholar, highlighting its popularity and applications.

The 2018 LPI report also mentions that there are several countries that are currently trying to improve their scores. Countries like India, Canada, France, etcetera. have set up special dedicated logistics bodies under a secretary to enact reforms and improvements. It is established that the LPI score is based on the six components listed in the previous section. Each of these components can be directly improved in certain ways. These can involve direct investment in infrastructure, better training given to logistics 
employees, fostering better trade relations, etcetera. According to (Arvis et al., pp.31, 2018), "Despite extensive mechanization and automation, logistics remains a people business" This thesis explores a new aspect that could have an impact on logistics performance and has not been studied before. Specifically, this research will investigate the relationship between different national culture dimensions of each country and their impact on the country's LPI score. This new perspective will offer insights that will influence managers and policy makers concerning understanding some of the international logistics dynamics as well as setting appropriate investment and improvement plans to advance logistics performance. A deeper understanding of national culture and its effect on the LPI can help approach the problem of logistics performance improvement in a better manner.

\subsection{Research Methodology}

This thesis begins with a detailed literature review of logistics and logistics performance. The impact and importance of logistics performance is then evaluated. The LPI is considered as the measure of the logistics performance of a country and the 2018 report by (Arvis et al., 2018) is analyzed in detail. Once the different factors that affect the LPI were analyzed, national culture was considered as a new factor that could affect the LPI. Further research on national culture led to the adoption of the Hofstede model as a measure of national culture; the interpretation section better defines the different dimensions of Hofstede's model and their impact on the LPI. The different applications of the Hofstede model were studied using available literature and it was found to be superior to other models like the GLOBE project (House et al., 2002) and the Shalom Schwartz model (Schwartz, 2008). 
On completion of the literature review, it became apparent that there was a gap in the understanding of the logistics performance of countries that could potentially be filled in by national culture. The two secondary datasets, the 2018 LPI and Hofstede's model of national culture, were first cleaned and statistical methods of data analysis were used to explore the relationship between them. The nature of this relationship was further analyzed and explored using available literature and statistics. A multiple regression model and correlation tests were used to explore the relationship between the LPI and national culture. A clustering analysis with both K-means and hierarchical clustering methods was performed and interactive maps were created for visualization. Based on the results of the analysis and the literature, conclusions were drawn about the actual effect of national culture on the LPI score. 


\section{Chapter 2-LITERATURE REVIEW}

\subsection{Logistics}

Logistics is one of the dynamic activities that enables the connection between production and consumption (Bartolacci, J. LeBlanc, Kayikci, \& Grossman, 2012). Logistics performance literature can be divided into different groups including logistics performance metrics, logistics performance analysis and logistics performance applications. In this review, some examples of each of these three mentioned groups are discussed.

A good review on logistics performance metrics can be found in (Enslow et al., 2005). Examples of research work dedicated to developing logistics performance metrics include Bowersox et al. (2000) who proposed to measure logistics performance through incorporating performance metrics such as customer satisfaction, delivery speed, delivery dependability, and delivery flexibility. Brewer and Speh (2000) considered service level, cost, and return on assets or investment as logistics metrics. A more comprehensive attempt includes Fugate et al. (2010) who proposed a model for logistics performance measurement depending on integration of logistics efficiency, logistics effectiveness and logistics differentiation. There has also been work done to determine the effect of supply chain performance on transport logistics (Lai, Ngai, \& Cheng, 2004). This work was approached from the perspective of discovering insights in supply chain performance in air and sea transport, freight forwarding, and third-party logistics services, from the perspective of cost and service. 
The second group of research focused on logistics performance analysis that received more attention within the larger supply chain literature. Examples include the work of Green Jr. et al. (2008) who proposed a logistics performance model incorporating logistics performance with supply chain management's strategy. Their results indicated that logistics performance is positively impacted by supply chain management strategy and that both logistics performance and supply chain management strategy positively influence marketing performance, which in turn positively affects financial performance. Schramm-Klein and Morschett (2006) assessed the relationship between logistics performance and the organizational performance of firms in the retail supply chain. The impacts of supply chain uncertainty and risk on the logistics performance was explored by Wang (2018). Fawcett and Cooper (1998) related logistics performance measurement to customer success using empirical data from 17 countries. Their paper mainly focused on the importance of performance measurement systems with the logistics sector as a focused example. They theorized that the traditional approach to logistics measurement is not adequate as it does not account for the needs of the customer and new manufacturing methods and developments like just in time manufacturing. They followed a similar survey-based questionnaire approach as the LPI targeted at logistics managers. Although firms in only 17 countries were studied, the final result of the paper was the formation of a logistics performance index with scores ranging up to 200 that was used to compare the logistics performance measurement of the top and bottom performers. This research shows that logistics measurement is constantly evolving, and several new factors need to be considered when measuring logistics performance. Aharonovitz et al. (2018) explored how logistics performance is affected by supply chain 
relationships through highlighting the relationships among supplier selection, relationship history, meetings, and logistics collaboration and logistics performance.

On the application level, many of the literature of logistics performance focused on specific countries' logistic performance. Examples include India (Chen and Paulraj 2004), Brazil (Conceição and Quintão, 2004) and Taiwan (Shang and Marlow 2007). More recently, logistics performance application research considered specific industries. Examples include electronics industry (Hajiesmaeili et al. 2016), construction industry (Ying et al. 2018), textile industry (Ülgen and Forslund 2015) and healthcare (Moons et al. 2019).

The logistics performance index is the primary measure of the logistics performance of countries. As one of the primary datasets being used in this thesis is the 2018 LPI dataset from the LPI report, it is important to understand more about the LPI. As mentioned earlier, the LPI is based on six major components. These components are used in the survey questionnaire that is given to the logistics professionals to calculate both the local and global LPI scores and ranks. The six major components that constitute the LPI are:

1) International shipments: This is a measure of how easy it is to arrange shipments at competitive prices.

2) Logistics quality and competence: This is a measure of the quality of logistics services and the satisfaction and relationship of the customer.

3) Tracking and tracing: This is a measure of how easy it is to track and trace any shipment at any given time until it is delivered to the final customer. 
4) Timeliness: This is a measure of whether the shipments arrive at the specified time. It is important due to the increasing competitiveness and can affect the relationship with customers.

5) Customs: This is a measure of how easy it is to deal with customs officials and the customs procedure in general. It depends on several factors such as trade relations, taxation, etc.

6) Infrastructure: This is a measure of the general infrastructure available for logistics. This includes structures such as ports, highways, airports, etc. and usually requires a large investment of time and money to improve.

The LPI is created biennially based on the survey results on these six components and the single value LPI score is on a scale from 1 to 5. In 2018, the highest scoring country is Germany with 4.19 and the lowest scoring country is Somalia with a score of 2. The other elements present in the dataset are the scores of the countries on all six components, their ranks and also the confidence intervals for the scores and ranks. A country is said to have improved its performance if the lower bound score is higher than its previous years upper bound score. The LPI can thus also be used to track improvements in logistics performance over the years for each country.

The only other noteworthy model that is similar to the LPI in scale is the FM global resilience index, which is a measure of the most resilient supply chains ranked across 130 countries. As the aim of this research is broader than the resiliency of supply chains and consists of logistics in general, this index was not considered. However, the results of this index were similar to the results of the LPI ranks as well with most of the same countries occupying the top 10 ranks albeit in a different order. 
The logistics performance research that considered specifically the LPI as a metric, explored the relationship between these metric and other parameters. Examples include investigating the LPI moderating role between the GDP and the global competitive index (Civelek, et al., 2015). Martí et al. (2014) discussed how each of the LPI factors affects international trade in emerging economies and how this can lead to improvements in logistics in these countries. This research was conducted by creating a gravity model and examining the effect of each of the components of the LPI on emerging economies. The findings from this paper suggested that improvements in any of the components of LPI could lead to improvements in trade flows. This was found to be especially applicable to countries in Africa, South America and Europe. According to data from the 2012 edition of the LPI report and (Domingues, Reis, \& Macário, 2015), logistics has an increasingly important role in the economy of the global marketplace representing approximately 8,5 percent of the gross domestic product (GDP) in the USA and accounting, on average, for 10 percent of the GDP of European countries. This research therefore also highlights how important the LPI is and the need to better understand it.

\subsection{National Culture}

There are many different cultures present all over the world. It is important to clearly understand how certain cultures differ from one another as these cultural differences can have significant consequences. A famous example that can be used to highlight this is the series of airplane crashes in Korea from the 1970's to the 2000's. This is explained by (Ghemawat \& Reiche, 2011). The paper reports that the principal reason for all the crashes that occurred were due to Korea's culture of people not 
questioning their superiors' decisions. The black box footage revealed that none of the copilots or flight engineers questioned the pilots. This is attributed to the high power distance of Korea. Another good example that is discussed in the same paper is in the form of a study conducted on different managers across the world. The managers were placed in a scenario where they were in a car that their close friend was driving. The car was said to be going at 15 miles per hour above the speed limit and to have collided with a pedestrian. The question posed to the managers was would they lie and say that the friend was driving at the speed limit to save him from the most severe consequences. The results of the study showed that most of the managers in Western countries refused to lie while only under $50 \%$ of managers from Asian countries said that they would refuse to lie. A possible reason for the differences between the collectivist culture in Asia unlike the individualistic culture in the West has been attributed to the farming of rice, which is a group activity requiring several farmers tow work together and rice is far more prominently grown and consumed in Asia as opposed to wheat, which does not require significant cooperation to grow (Laskowska-Rutkowska, 2009).

There has been plenty of research conducted on creating models based on national culture. The most famous is Hofstede's model that is used in this thesis. Another model that was considered was the work by (Bond et al., 1987) This model was similar to Hofstede's, except it used students from Asia for the survey instead of employees from IBM. This research was conducted after the Hofstede model was first established in order to test certain critiques of the Hofstede model. One of the critiques of the Hofstede model was that it used data only from employees and that they may not accurately represent the entire culture of that country. Another critique was that the survey questions of the 
Hofstede model were all created by a person from the West and written in English, and that this could have an impact on the responses as well. The results from this Chinese model helped validate Hofstede's model as three of the four uncovered dimensions in this research were very similar to three of Hofstede's four initial dimensions. As the questions in this model were created with the help of Chinese scholars, written in Chinese and given to students, they helped validate Hofstede's model. Hofstede also accepted the one new dimension that was uncovered and termed it as long-term orientation in his updated model. The other widely used model is the Globe Project which is viewed as a direct competitor to the Hofstede model (House et al., 2002). The aim of the research was to study various cultures and determine the effect of culture on organizational behavior, effectiveness and leadership. It is fairly similar to Hofstede's model, except it had nine dimensions instead of six and focused on thousands of responses from mid-level managers in various industries in 61 countries. The GLOBE project is still not complete however and the final phase of the project is being funded and worked upon. Another model that was considered was the Schwartz model (Schwartz, 2008) However, the fact that these models did not have as many cited works as the Hofstede model led to them not being used. The Hofstede model was chosen because it is the most widely accepted and cited model and has been validated and updated several times.

Hofstede's framework proposed a four-dimensional model of national culture, which was later expanded to six dimensions as follows (Hofstede 2011):

1. Power Distance, related to the different solutions to the basic problem of human inequality. 
2. Uncertainty Avoidance, related to the level of stress in a society in face of an unknown future.

3. Individualism Vs Collectivism, related to the integration of individuals into primary groups.

4. Masculinity Vs Femininity, related to preference in society for achievement, assertiveness and material rewards for success vs cooperation, modesty, caring for the weak and quality of life.

5. Long Term versus Short Term Orientation, related to the choice of focus for people's efforts: the future or the present and past.

6. Indulgence versus Restraint, related to the gratification versus control of basic human desires related to enjoying life.

Hofstede's model has been applied in several scenarios. It has been used to check the effect of national culture on the level of innovation by (Prim, Filho, Zamur, \& Di Serio, 2017). This research was conducted using Hofstede's dimensions of national culture and testing their relationship with the global innovation index using a multiple linear regression model with a sample size of 72 countries. The findings proved that there was indeed a relationship between certain dimensions and the level of innovation. Some of the other noteworthy applications of Hofstede's model are, determining the impact of national culture on GDP (Cox, Friedman, \& Tribunella, 2011), comparing education performances of different cultures using immigrants from Florida as a focused example (Figlio, Giuliano, Özek, \& Sapienza, 2017), international marketing analysis (Soares, 
Farhangmehr, \& Shoham, 2007), etc. It has also been used to determine if long term orientation mindsets can increase the value and operating performance of firms (Flammer and Bansal 2017). This is tested by examining the change stock market prices based on if the executive plans are short term or long term. The operational performance is measured by the growth and profit of the firm after long term projects. Hofstede's model has even been replicated by (Merritt, 2000) in a study on the application of the model to pilots. The study involved replicating the entire Hofstede questionnaire and applying it to pilots from 23 countries. The results revealed that Hofstede's dimensions were relatively consistent over time and that "one size fits all" training is inappropriate. Thus, both Hofstede's model and its individual dimensions have a very wide range of applications.

\subsection{Connection}

It is important to note that some previous work had been conducted to relate national culture with the supply chain. It has been used to determine the impact of national culture on supply chain disaster mitigation (Kumar, Liu, \& Demirag, 2015). This paper utilized all of Hofstede's dimensions of national culture excluding indulgence to determine if national culture had an impact on supply chain disaster mitigation abilities of companies in different countries. The results of the weighted least squares regression and factorial analysis revealed that all of these dimensions were partly responsible for the difference is disruption planning and response of the companies in different countries. The Globe model has been used to determine the effect of national culture on supply chain integration practices (Wong, Sancha, \& Thomsen, 2017). Five dimensions of Hofstede's model were also found to have an impact on agile supply chain management (Santos, Fogaça, de Souza, Marinho Toledo, \& Guimarães Gandra, 2012). There has also 
been research into the effect of national culture on operations management research (Pagell, Katz, \& Sheu, 2005). This research made use of secondary datasets as well. It utilized both the Hofstede model as well as the Trompenaars as a measure of national culture. The subset of the data from the Global Manufacturing Research Group (GMRG) manufacturing practices survey was also used, and a hierarchical regression was conducted. The results found that national culture significantly explained international operations management behavior among similar manufacturing plants in the same industry located in different cultures. The Hofstede model is used as one of the factors that affects the sharing of information in global supply chains (Shore, 2001). As already discussed earlier in this section, logistics performance is found to affect marketing success. Another factor that is considered for marketing is national culture. Research has indicated that the different dimensions of Hofstede's model of national culture affect the nature of advertisements (Alden, Hoyer, \& Lee, 1993). This paper discusses the effect of humor in advertisements from a cultural perspective. It finds that high power distance countries like Vietnam and Thailand usually incorporate humor with characters of unequal status which is not the case in low power distance countries like Germany and the United States of America.

"Service quality can differ substantially at similar levels of perceived infrastructure quality. Even high-quality "hard" infrastructure cannot substitute for operational excellence, based on "soft" infrastructure such as professional skills and smooth business and administrative processes" (Arvis et al., pp.4, 2018). This is a clear indication that people and their skills could influence the LPI. The LPI report also suggests that logistics performance is much more than just income. Countries such as 
India, China, Rwanda, etc. all outperform their economic peers. On the flip side, resource rich countries like Bhutan, Iraq, etc. all underperform. This is shown in greater detail in figure 1

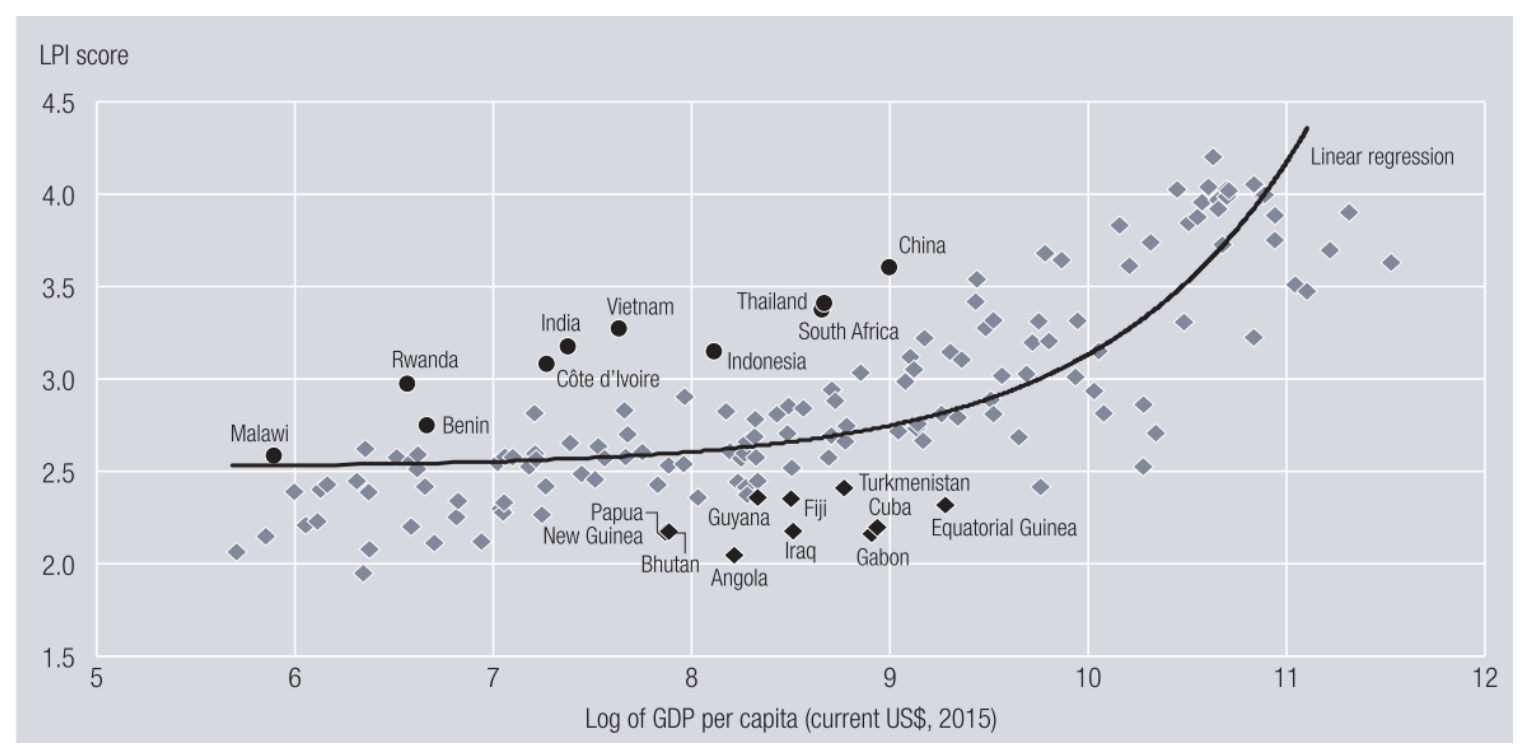

Figure 1: LPI overperformers and underperformers (LPI report 2018)

The paper by (Guner \& Coskun, 2012) discusses the effect of economic and social factors on the logistics performance of countries. The 2012 edition of the same LPI data that is used in this thesis was used as a measure of logistics performance by these researchers. The countries that were studied consisted of 26 Organization for Economic Co-operation and Development (OECD) countries. The economic indicators that were considered were the GDP, Transportation infrastructure gross investment spending (INV) and economic growth rates. The social factors that were considered consisted of political risk, democracy index and human development index. The correlation tests that were performed revealed that the economic factors did not directly affect the LPI for these countries. The social factors, however, were all significantly correlated with the LPI. This 
suggests that there are several factors that must be considered to better explain the LPI scores. As the appendix section containing the list of work using the LPI of the (Arvis et al., 2018) shows there has been no direct research that has been done on the impact of national culture on the logistics performance of countries.

The above review highlights how logistics performance literature focused mainly on how to measure that performance and the relationships between such performance and various supply chain operational and strategic dynamics. Some of that literature review also explored the LPI relationship with different economical aspects. However, very few researchers attempted to explore the relationship between social aspects and logistics performance. More specifically, no work to the knowledge of the author had explored the impact of national culture (as a social noneconomic aspect) with the LPI (as a wellrecognized logistics performance metric). This thesis contributes to the logistics performance literature through attempting to fill some of this existing research gap by investigating the relationship between Hofstede's national culture dimensions and the LPI. 


\section{Chapter 3-ANALYSIS AND RESULTS}

\subsection{Data Gathering and Information}

The LPI report by (Arvis et al., 2018) was selected for the analysis as it is updated every two years and is also the most comprehensive report available. It also contained all the data required for our analysis, the procedures followed to obtain the data, along with several useful insights as well. As mentioned earlier, secondary data for both the LPI scores as well as the dimensions of national culture were used in this research. The dataset for the 2015 Hofstede model with all scores between 0 and 100 was obtained from (Hofstede, 2015) and the latest 2018 LPI results dataset from (Arvis et al., 2018). The 2011 model by Hofstede included the 5th and 6th dimension of national culture, i.e. long term orientation and indulgence (Hofstede, Hofstede \& Minkov, 2010).

As Hofstede first created his model in the 1980's, the question of his model's validity in the current time period can be raised. A lot has changed since the 1980's and the world is not the same now as it once was. In order to ensure the validity of Hofstede's work today, the work by (Beugelsdijk, Maseland, \& van Hoorn, 2015) is referred. In this

paper, the work of Hofstede is replicated, and the results showed that while the scores of countries have changed over time, they have not changed significantly relative to each other. This paper, along with the fact that the Hofstede data is regularly updated, validate the use of his model even today.

\subsection{Hypotheses}

In order to determine and explore the effect of national culture on the logistics performance of countries, a hypothesis format was selected. Using these hypotheses, with 
one for each dimension of national culture, the individual effects of all the dimensions of national culture on the LPI can be determined. The significant results can be further interpreted and analyzed using available literature as well.

Hol: Power Distance has no effect on the LPI Score of a country HA1: Power Distance has an effect on the LPI Score of a country

Ho2: Uncertainty Avoidance has no effect on the LPI Score of a country HA2: Uncertainty Avoidance has an effect on the LPI Score of a country

Ho3: Long Term Orientation has no effect on the LPI Score of a country HA3: Long Term Orientation has an effect on the LPI Score of a country

Ho4: Individualism has no effect on the LPI Score of a country HA4: Individualism has an effect on the LPI Score of a country

Ho5: Masculinity has no effect on the LPI Score of a country HA5: Masculinity has an effect on the LPI Score of a country

Ho6: Indulgence has no effect on the LPI Score of a country HA6: Indulgence has an effect on the LPI Score of a country

\subsection{Data Processing}

In order to prepare the data, all data points with missing values were first removed from the dataset. This resulted in Hofstede's initial dataset of 111 countries being reduced to 65 countries. Only the common countries present in both datasets were then retained. This was done using Microsoft Excel and RStudio. A portion of this had to be done 
manually by inspection as well due to a few identical countries being labelled differently in both datasets such as South Korea vs Korea Republic. The unnecessary variables from the LPI dataset such as the LPI ranks and the scores on each of the individual components were then removed. These two datasets were then merged by the "country" variable. The latitudes and longitudes of all the countries in the dataset were then obtained and added to the dataset for use in the creation of the maps. The final dataset contained 62 countries with the overall LPI score as the response and six columns, one for each of Hofstede's dimensions, as the independent variables along with the latitudes and longitudes of all the countries for a total of 620 data points. The weighted aggregated LPI scores of the four most recent surveys were used as the response variable because the LPI report stated that this is a more accurate depiction of a country's logistical performance, as it reduces the variation from one LPI survey to another. Minitab version 18 and RStudio were used for the statistical analysis and Tableau was used for the visualizations. Both hierarchical and K-means clustering analysis were attempted using RStudio and Tableau. The data was first normalized for the clustering analysis using the "scale" command in RStudio. The country names were then assigned as the row names as this is the required format for clustering in RStudio. The results of the complete analysis are discussed in the next section and the entire dataset used is present in the appendix section A of this thesis. An interactive map was also created using Tableau to get a better visualization of the data.

\subsection{Statistical Tests and Results}

In this research, the main effects of LTO, Power Distance, Individualism and Uncertainty Avoidance and Masculinity were explored on the aggregated 2018 LPI scores of countries by using both a Pearson's correlation test and a multiple linear 
Regression model. A Grubbs test was first run to ensure that all the used data separately did not contain any outliers as a modified form of two secondary datasets is being used. The results of the test in table 1 confirmed this assumption. The high $\mathrm{P}$ values indicated in table 1 ensure that the null hypothesis is not rejected and that all the values come from the same populations and there are no outliers at a level of significance of 5\%

Table 1. Grubbs test results

\begin{tabular}{|l|r|r|r|r|r|r|r|}
\hline Variable & $\mathrm{N}$ & Mean & StDev & Min & Max & $\mathrm{G}$ & $\mathrm{P}$ \\
\hline LPI Score & 62 & 3.3677 & 0.4920 & 2.3700 & 4.1900 & 2.03 & 1.000 \\
\hline Power Distance & 62 & 58.48 & 20.36 & 11.00 & 100.00 & 2.33 & 1.000 \\
\hline Individualism & 62 & 45.76 & 23.68 & 12.00 & 91.00 & 1.91 & 1.000 \\
\hline Masculinity & 62 & 48.95 & 19.83 & 5.00 & 100.00 & 2.57 & 0.515 \\
\hline Uncertainty Avoidance & 62 & 66.65 & 22.63 & 8.00 & 100.00 & 2.59 & 0.488 \\
\hline Long Term Orientation & 62 & 49.74 & 22.87 & 12.59 & 100.00 & 2.20 & 1.000 \\
\hline Indulgence & 62 & 47.53 & 22.36 & 0.00 & 100.00 & 2.35 & 1.000 \\
\hline
\end{tabular}

A best subsets Regression was first run with the LPI score as the response and all six dimensions of national culture as the free predictors. Using these results shown in table 2, it was found that the model with all of the five dimensions of national culture excluding Masculinity, explained the most uncertainty and had the highest Rsq, adjusted Rsq and Rsq predictability. It also had a suitable Mallows Cp index score as well. 
Table 2. Best Subsets Regression

\begin{tabular}{|c|c|c|c|c|c|c|c|c|c|c|c|}
\hline Vars & $\mathrm{R}-\mathrm{Sq}$ & $\begin{array}{c}\mathrm{R}-\mathrm{Sq} \\
\text { (adj) }\end{array}$ & $\begin{array}{r}\mathrm{R}-\mathrm{Sq} \\
\text { (pred) }\end{array}$ & $\begin{array}{r}\text { Mallows } \\
\mathrm{Cp} \\
\end{array}$ & $S$ & \begin{tabular}{|l}
$\mathrm{P}$ \\
$\mathrm{o}$ \\
$\mathrm{w}$ \\
$\mathrm{e}$ \\
$\mathrm{r}$ \\
$\mathrm{D}$ \\
$\mathrm{D}$ \\
$\mathrm{i}$ \\
$\mathrm{s}$ \\
$\mathrm{t}$ \\
$\mathrm{a}$ \\
$\mathrm{n}$ \\
$\mathrm{c}$ \\
$\mathrm{e}$ \\
\end{tabular} & \begin{tabular}{|l|}
$\mathrm{I}$ \\
$\mathrm{n}$ \\
$\mathrm{d}$ \\
$\mathrm{i}$ \\
$\mathrm{v}$ \\
$\mathrm{i}$ \\
$\mathrm{d}$ \\
$\mathrm{u}$ \\
$\mathrm{a}$ \\
$\mathrm{l}$ \\
$\mathrm{i}$ \\
$\mathrm{s}$ \\
$\mathrm{m}$ \\
\end{tabular} & $\begin{array}{l}\mathrm{M} \\
\mathrm{a} \\
\mathrm{s} \\
\mathrm{c} \\
\mathrm{u} \\
\mathrm{l} \\
\mathrm{i} \\
\mathrm{n} \\
\mathrm{i} \\
\mathrm{t} \\
\mathrm{y}\end{array}$ & \begin{tabular}{|l}
$\mathrm{U}$ \\
$\mathrm{n}$ \\
$\mathrm{c}$ \\
$\mathrm{e}$ \\
$\mathrm{r}$ \\
$\mathrm{t}$ \\
$\mathrm{a}$ \\
$\mathrm{i}$ \\
$\mathrm{n}$ \\
$\mathrm{t}$ \\
$\mathrm{y}$ \\
$\mathrm{A}$ \\
$\mathrm{A}$ \\
$\mathrm{v}$ \\
$\mathrm{o}$ \\
$\mathrm{i}$ \\
$\mathrm{d}$ \\
$\mathrm{a}$ \\
$\mathrm{n}$ \\
$\mathrm{c}$ \\
$\mathrm{e}$ \\
\end{tabular} & \begin{tabular}{|l}
$\mathrm{L}$ \\
$\mathrm{o}$ \\
$\mathrm{n}$ \\
$\mathrm{g}$ \\
$\mathrm{T}$ \\
$\mathrm{T}$ \\
$\mathrm{e}$ \\
$\mathrm{r}$ \\
$\mathrm{m}$ \\
$\mathrm{O}$ \\
$\mathrm{O}$ \\
$\mathrm{r}$ \\
$\mathrm{i}$ \\
$\mathrm{e}$ \\
$\mathrm{n}$ \\
$\mathrm{t}$ \\
$\mathrm{a}$ \\
$\mathrm{t}$ \\
$\mathrm{i}$ \\
$\mathrm{o}$ \\
$\mathrm{n}$ \\
\end{tabular} & $\begin{array}{l}\mathrm{I} \\
\mathrm{n} \\
\mathrm{d} \\
\mathrm{u} \\
\mathrm{l} \\
\mathrm{g} \\
\mathrm{e} \\
\mathrm{e} \\
\mathrm{c} \\
\mathrm{e}\end{array}$ \\
\hline 1 & 36.5 & 35.5 & 32.5 & 37.4 & 0.39525 & & $X$ & & & & \\
\hline 1 & 28.4 & 27.2 & 24.5 & 49.7 & 0.41981 & $X$ & & & & & \\
\hline 2 & 49.9 & 48.2 & 45.0 & 19.3 & 0.35396 & & $X$ & & & $X$ & \\
\hline 2 & 47.1 & 45.3 & 41.8 & 23.5 & 0.36380 & $X$ & & & & $X$ & \\
\hline 3 & 56.6 & 54.3 & 50.3 & 11.3 & 0.33249 & & $X$ & & & $X$ & $X$ \\
\hline 3 & 55.3 & 53.0 & 48.9 & 13.2 & 0.33742 & & $X$ & & $X$ & $X$ & \\
\hline 4 & 61.3 & 58.6 & 53.7 & 6.1 & 0.31644 & & $X$ & & $X$ & $X$ & $X$ \\
\hline 4 & 59.4 & 56.5 & 51.7 & 9.1 & 0.32444 & $X$ & $X$ & & & $X$ & X \\
\hline 5 & 63.4 & 60.2 & 54.2 & 5.0 & 0.31058 & $X$ & $X$ & & $X$ & $X$ & $X$ \\
\hline 5 & 61.5 & 58.0 & 51.6 & 8.0 & 0.31880 & & $X$ & $X$ & $X$ & $X$ & $X$ \\
\hline 6 & 63.4 & 59.4 & 52.5 & 7.0 & 0.31338 & $X$ & $X$ & $X$ & $X$ & $X$ & $X$ \\
\hline
\end{tabular}


Before moving forward with the multiple linear regression, it was necessary to check the underpinning assumptions for any regression, i.e. normality, constant variances and independency. These results are shown in the four in one graph in figure 2. Due to the nature of the data (as demonstrated by the secondary sources that are being used), independency can easily be accounted for. The normality assumption was accounted for by using the Anderson Darling test and the normal probability plot. The high $\mathrm{p}$ value of 0.432 and the shape of the graph both indicate clear normality of the data. A plot of the Residuals versus Fitted values revealed that the variances were constant as well. A mild cone like shape was however noticed in this plot. In order to ensure the validity of the conclusion that the variances were indeed constant, a Breuch-Pagan test was run using RStudio and the results matched the initial conclusion that the variances were indeed constant. The p value was 0.4147 and the BP value was 5.0099 and the null hypothesis that the variances were constant could avoid being rejected. The same assumptions were also verified in the model without using the Masculinity dimension and these graphs are shown in figure 3. 


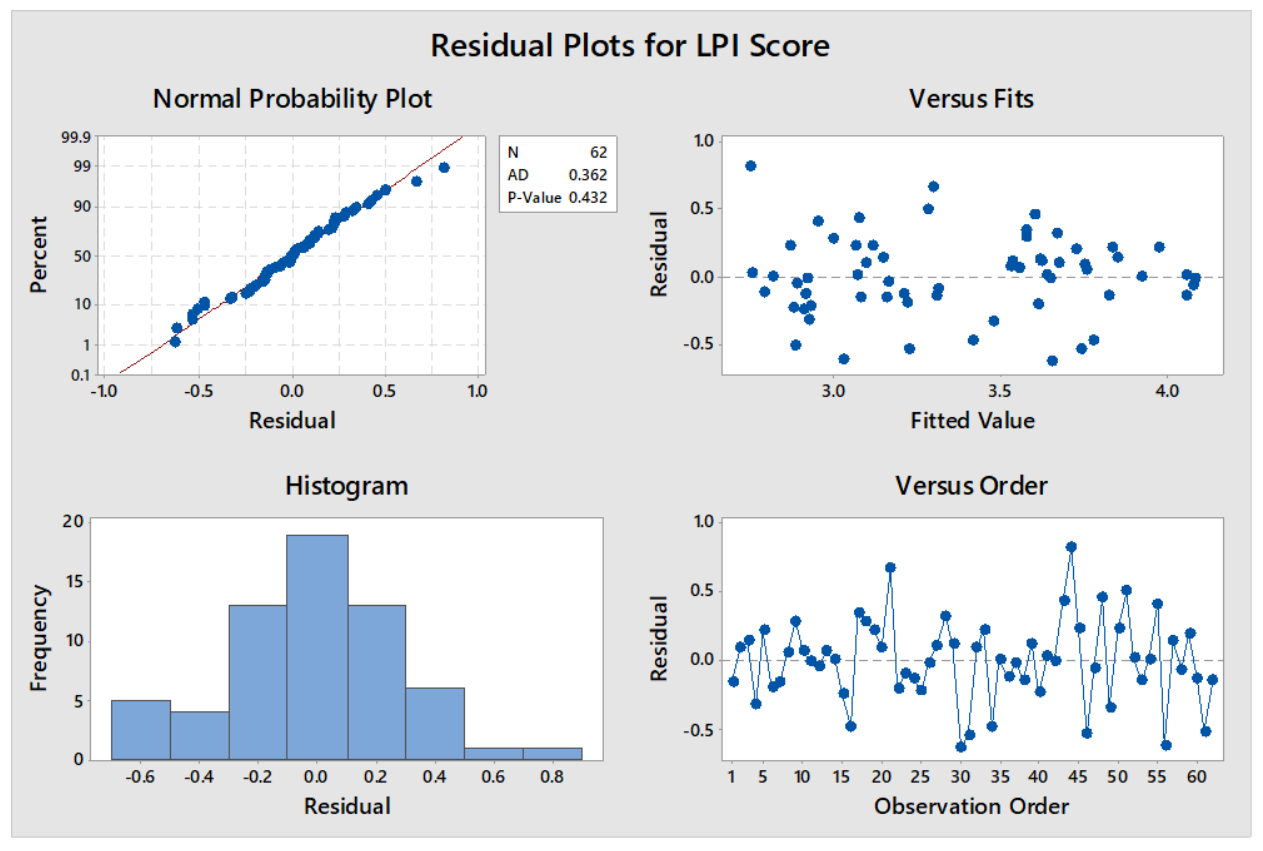

Figure 2: Assumptions of Regression

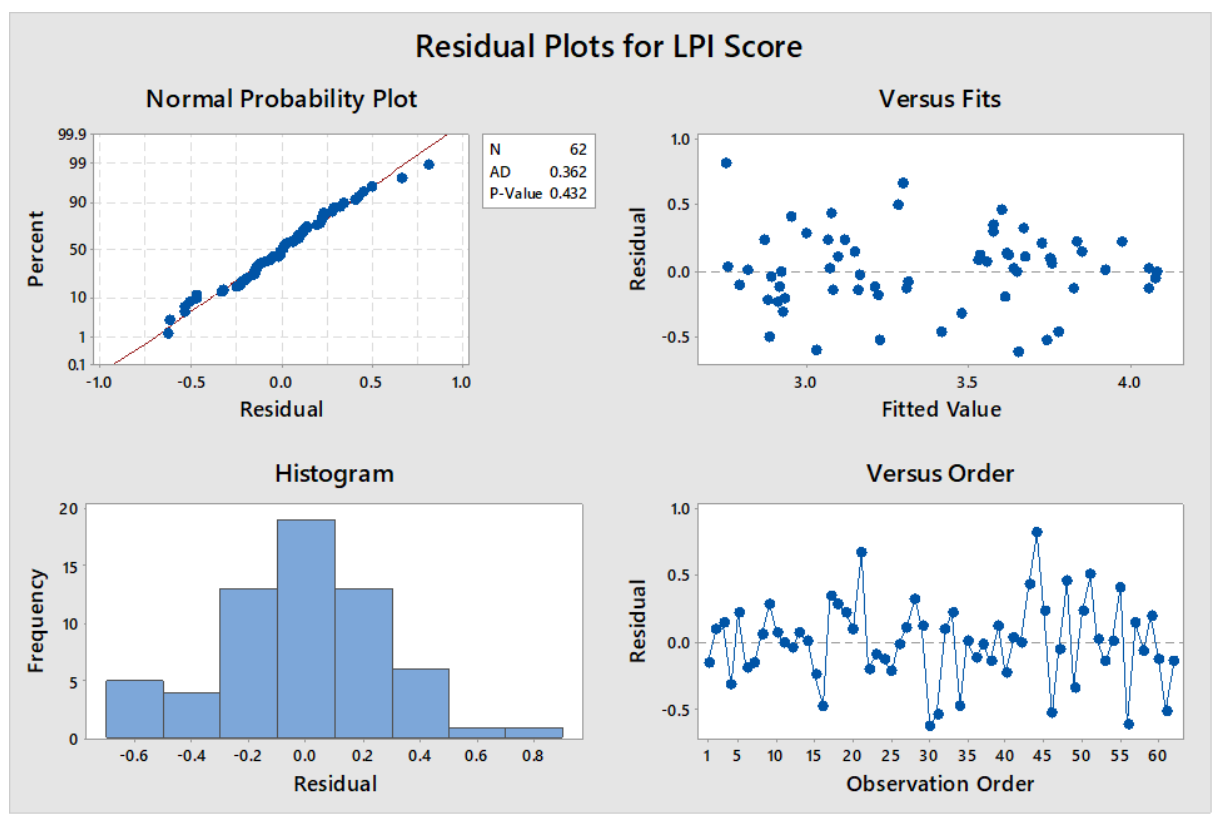

Figure 3: Assumptions without Masculinity 
Once the assumptions were validated, a multiple linear regression analysis was conducted. These results are shown in table 3 and the model summary in table 4 . Although the Rsq values may seem low, it should be noted that experiments involving scientific phenomenon typically would be expected to have rather high Rsq values, however when the data comes from human beings, surveys and emotions, the Rsq values that were obtained are quite high and indicate a suitable model (Frost, 2018). The variable inflation factors of all the terms in the model were below two and this indicates a lack of multicollinearity as shown in table 5. Although a higher order model with more interactions may have had higher Rsq values, it was found that the VIF increased exponentially and the model would also lose its stability.

Table 3. Analysis of Variance

\begin{tabular}{|l|r|r|r|r|r|}
\hline Source & DF & Adj SS & Adj MS & F-Value & P-Value \\
\hline Regression & 5 & 9.3645 & 1.87290 & 19.42 & 0.000 \\
\hline Power Distance & 1 & 0.3058 & 0.30583 & 3.17 & 0.080 \\
\hline Individualism & 1 & 1.0214 & 1.02143 & 10.59 & 0.002 \\
\hline Uncertainty Avoidance & 1 & 0.5980 & 0.59804 & 6.20 & 0.016 \\
\hline Long Term Orientation & 1 & 2.7842 & 2.78420 & 28.86 & 0.000 \\
\hline Indulgence & 1 & 0.6112 & 0.61119 & 6.34 & 0.015 \\
\hline Error & 56 & 5.4018 & 0.09646 & & \\
\hline Total & 61 & 14.7663 & & & \\
\hline
\end{tabular}

Table 4. Model Summary

\begin{tabular}{|r|r|r|r|}
\hline $\mathrm{S}$ & R-sq & R-sq(adj) & R-sq(pred) \\
\hline 0.310581 & $63.42 \%$ & $60.15 \%$ & $54.25 \%$ \\
\hline
\end{tabular}


Table 5. Coefficients and VIF

\begin{tabular}{|l|r|r|r|r|r|}
\hline & & & & & \\
\hline Term & Coef & SE Coef & T-Value & P-Value & VIF \\
\hline Power Distance & 2.797 & 0.330 & 8.47 & 0.000 & \\
\hline Individualism & -0.00479 & 0.00269 & -1.78 & 0.080 & 1.90 \\
\hline Uncertainty Avoidance & 0.00729 & 0.00224 & 3.25 & 0.002 & 1.78 \\
\hline Long Term Orientation & -0.00449 & 0.00180 & -2.49 & 0.016 & 1.05 \\
\hline Indulgence & 0.00554 & 0.00207 & 5.37 & 0.000 & 1.42 \\
\hline
\end{tabular}

The regression equation for the model can be expressed as: LPI Score $=2.797$ 0.00479 Power Distance + 0.00729 Individualism - 0.00449 Uncertainty Avoidance + 0.01111 Long Term Orientation + 0.00554 Indulgence.

The correlation test results in table 6 showed that four of these five factors were all significantly correlated with the LPI score as well. All the correlation results are based on a 5\% significance level. The correlation test results also indicated that both Indulgence and Masculinity are not significantly correlated with LPI score. However, the best subsets regression results in table 1 revealed that only masculinity is not significant for the regression model. This fact coupled with the results of the multiple regression, shown in table 3, indicates that indulgence acts as a suppressor in the model. This implies that it improves the Rsq of the regression model and is significant in the regression model, but it is not significantly directly correlated with the LPI score. 
Table 6. Pearson's Correlation Matrix

\begin{tabular}{|c|c|c|c|c|c|c|}
\hline & $\begin{array}{r}\text { LPI } \\
\text { Score }\end{array}$ & $\begin{array}{r}\text { Power } \\
\text { Distance }\end{array}$ & Individualism & Masculinity & \begin{tabular}{|} 
Uncertainty \\
Avoidance
\end{tabular} & $\begin{array}{l}\text { Long Term } \\
\text { Orientation }\end{array}$ \\
\hline \multirow[t]{2}{*}{$\begin{array}{l}\text { Power } \\
\text { Distance }\end{array}$} & 0.533 & & & & & \\
\hline & 0.000 & & & & & \\
\hline \multirow[t]{2}{*}{ Individualism } & 0.604 & -0.651 & & & & \\
\hline & 0.000 & 0.000 & & & & \\
\hline \multirow[t]{2}{*}{ Masculinity } & 0.008 & 0.154 & 0.030 & & & \\
\hline & 0.950 & 0.233 & 0.816 & & & \\
\hline \multirow{2}{*}{$\begin{array}{l}\text { Uncertainty } \\
\text { Avoidance }\end{array}$} & 0.345 & 0.212 & -0.191 & 0.026 & & \\
\hline & 0.006 & 0.099 & 0.138 & 0.841 & & \\
\hline \multirow{2}{*}{$\begin{array}{l}\text { Long Term } \\
\text { Orientation } \\
\end{array}$} & 0.418 & 0.028 & 0.088 & 0.017 & -.025 & \\
\hline & 0.001 & 0.830 & 0.499 & 0.893 & .849 & \\
\hline \multirow[t]{2}{*}{ Indulgence } & 0.117 & -0.305 & 0.158 & 0.080 & -.067 & -.513 \\
\hline & 0.366 & 0.016 & 0.220 & 0.535 & .605 & 0.000 \\
\hline
\end{tabular}

As mentioned in the previous section, both K-means and agglomerative hierarchical clustering methods were attempted on this dataset and their results are shown in figures 5 and 6 respectively. Figure 4 shows the initial test to discover the optimal number of clusters. The gap test revealed that six clusters were the optimal amount to be selected. This test was conducted with and without the masculinity dimension and showed no difference. The visualization from RStudio in figure 5 showed the grouping of 
these six clusters. These results however did not make sense from a logical and literaturebased standpoint. An alternate more automated cluster grouping was created using Tableau. This figure is attached in the Appendix B section. In order to check if the data was truly able to be clustered, the Hopkins test was run on RStudio. As the Hopkins test statistic was only 0.37 , which is not close to 1 , it was concluded that this data is not suitable for a clustering analysis.

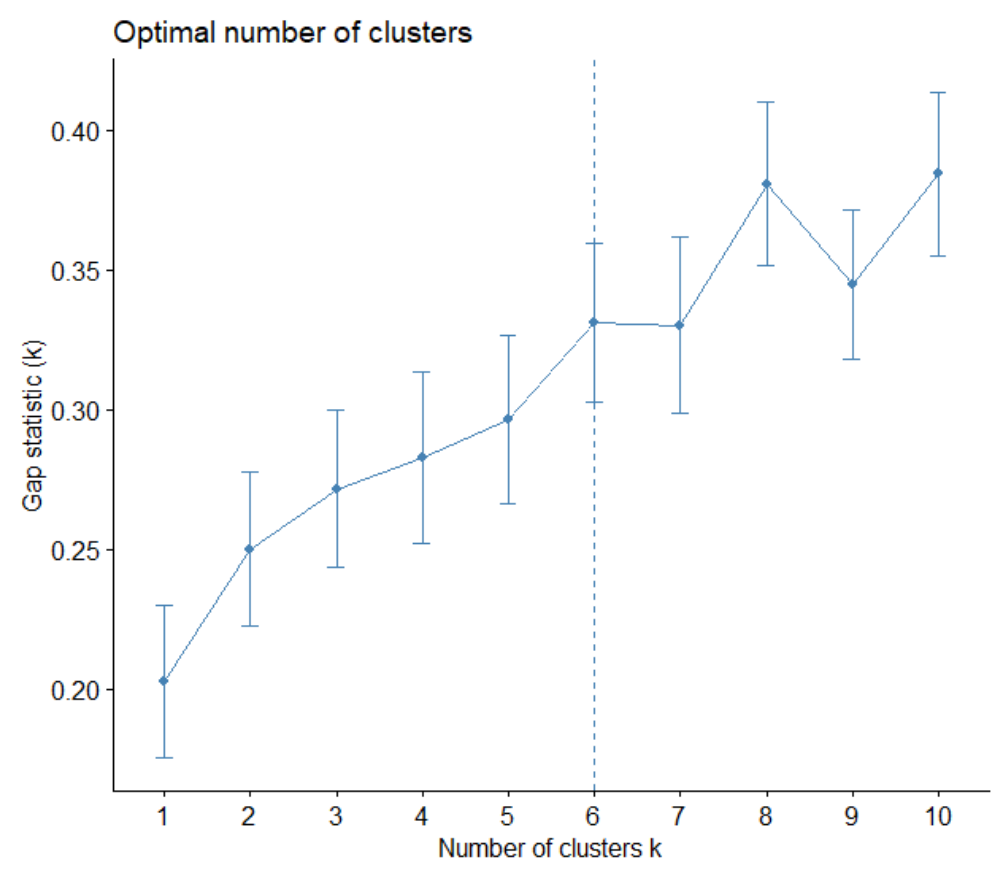

Figure 4: Gap test results 


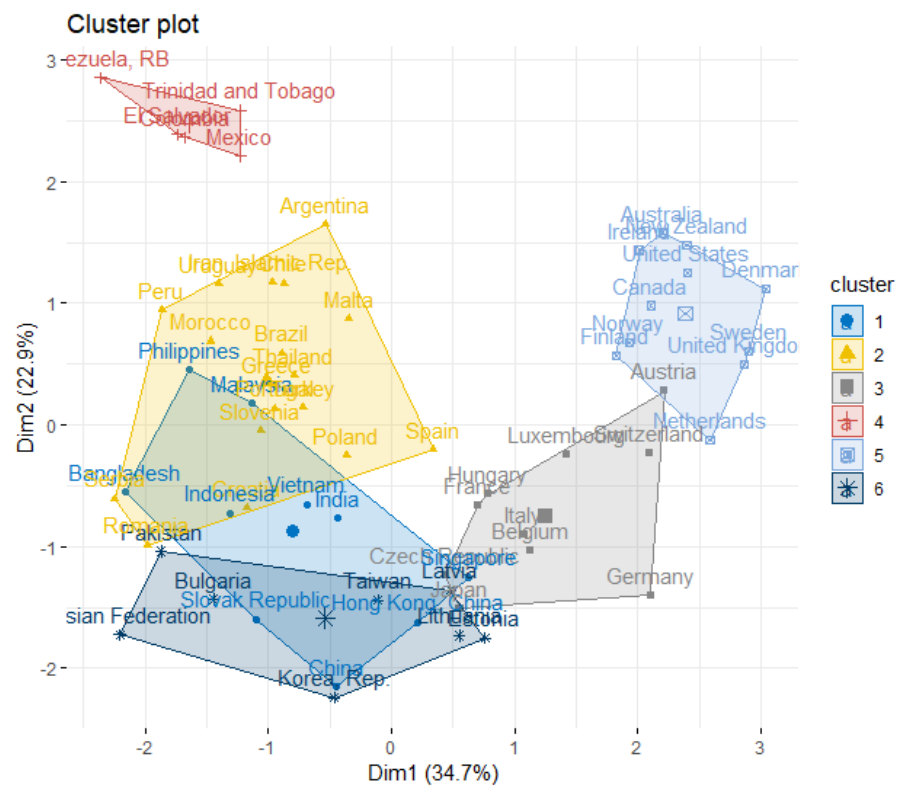

Figure 5: K-Means Cluster Plot

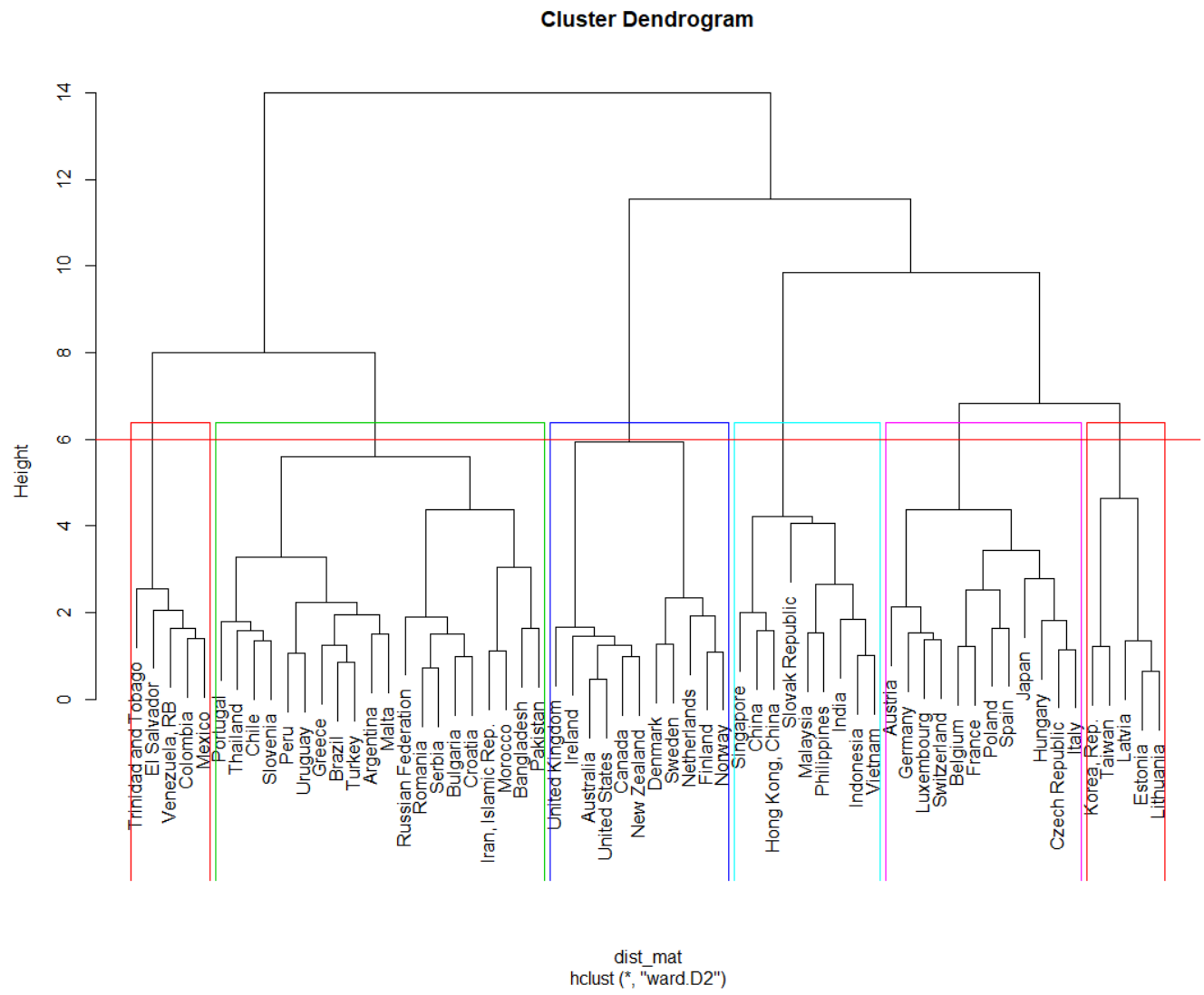

Figure 6: Hierarchical cluster dendrogram 
An interactive map was created using Tableau to help better visualize the LPI scores of countries. This is shown in figure 7. This map follows a color-based approach where countries are colored from light to dark blue based on the increasing magnitude of their LPI scores. This map can also be altered to compare the effects of individual dimensions of national culture and the LPI score for greater visual analysis if required. The remaining comparative maps are present in the appendix section of this thesis.

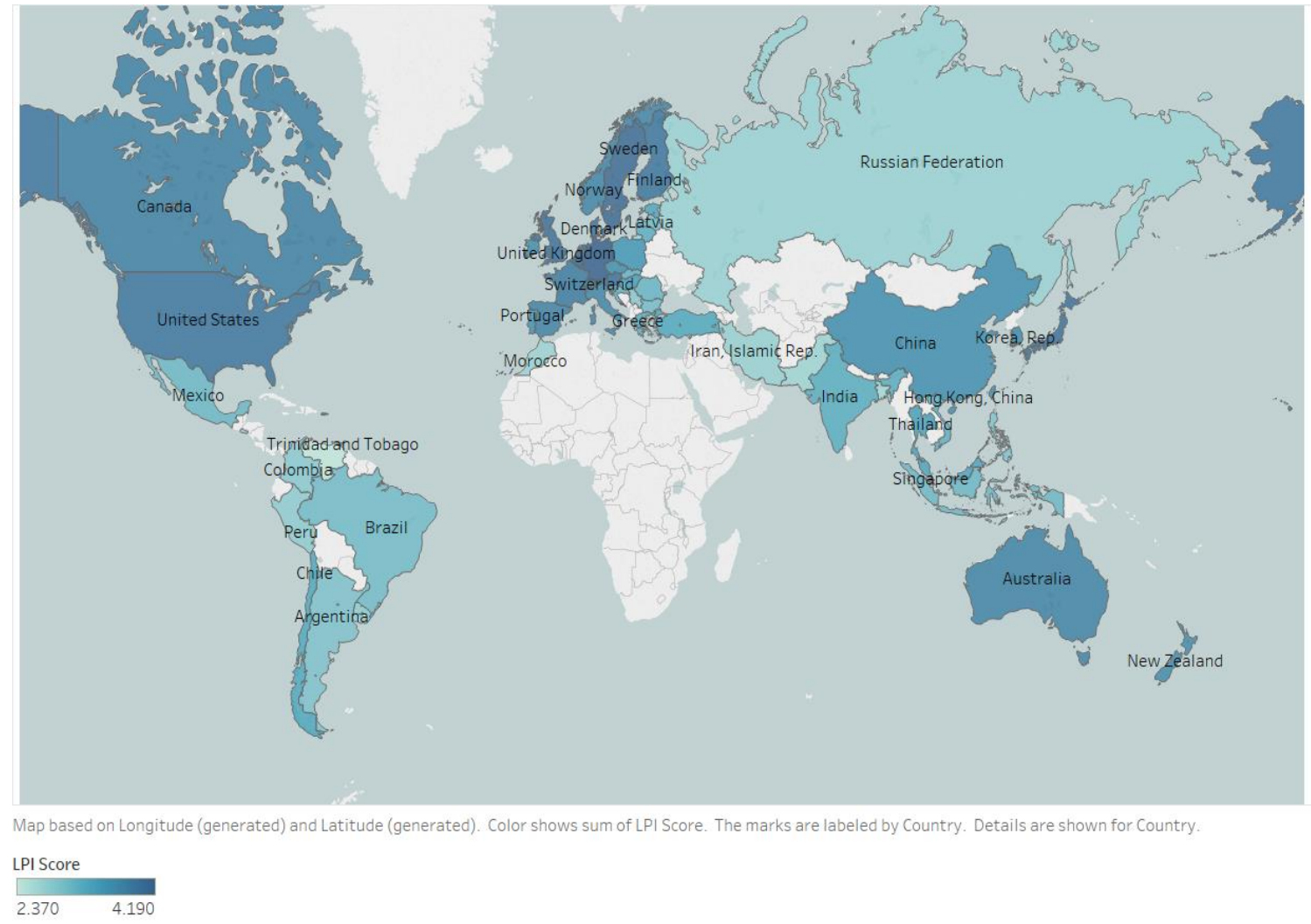

Figure 7: Map colored with LPI scores 


\section{Chapter 4-RESULTS INTERPRETATION}

\subsection{Summary Table}

Table 7. Pearson's Correlation Results Summary

\begin{tabular}{|l|l|l|l|}
\hline Dimension & $\begin{array}{l}\text { Pearson's } \\
\text { Coefficient }\end{array}$ & P Value & Result \\
\hline Power Distance & -.533 & 0.000 & Significant Effect \\
\hline Individualism & .604 & 0.000 & $\begin{array}{l}\text { No } \\
\text { Effect Significant }\end{array}$ \\
\hline Masculinity & .008 & 0.950 & $\begin{array}{l}\text { No Significant } \\
\text { Effect }\end{array}$ \\
\hline Indulgence & .117 & 0.366 & Significant Effect \\
\hline Long Term Orientation & .418 & 0.001 & Significant Effect \\
\hline Uncertainty Avoidance & -.345 & .006 & \\
\hline
\end{tabular}

Table 7 provides a summary of the main results obtained in the analysis section.

The implications based on the hypotheses and the results are discussed in the following section. Based on the results obtained, only the fifth and sixth null hypotheses cannot be rejected. That is, we fail to reject that Indulgence and Masculinity have no effect on the LPI.

The indulgence dimension is omitted from the interpretation section because it acts as a suppressor in the model. It does not, from a logical and literature-based standpoint, influence the LPI. It can however be explored further with future work. The Masculinity dimension is omitted because the results showed that it does not have any significant effect on the LPI score and including it would lower the adjusted Rsq of the regression model. 


\subsection{Interpretation}

\subsubsection{Power Distance}

Power Distance can be defined as "the extent to which the less powerful members of organizations and institutions (like the family) accept and expect that power is distributed unequally. This represents inequality (more versus less), but defined from below, not from above" (Hofstede, pp.9, 2011). Thus, power distance is a measure of how readily people accept differences in status. Countries with a high power distance are usually more inclined to have rigid regimes and their employees are usually more driven by dictated tasks rather than being encouraged to challenge the norms or the superiors. Power distance is also negatively correlated with GNP, and the LPI scores of highincome economies are usually higher than low income economies (Arvis et al., 2018). In this kind of environment of rigid bureaucracy as well as struggling economy, one would expect that power distance would negatively impact logistics performance. On the other hand, good logistics performance consists of effective communication and coordination, which is favored by a low power distance, as it would allow people to interact openly as equals, and not in a rigid manner. This is validated by (Matusitz \& Musambira, 2013), where they proved that power distance is negatively correlated with communication technology indicators, i.e. cell phone subscription, Internet use, and the number of telephone mainlines. This point is further substantiated by the fact that "due to a lack of input from lower level employees as well as poor communication and information sharing, quality of decisions is poorer in a high power distance organization" (Khatri, pp.1, 2009). In order for countries to improve their logistics performance, reforms could include several different agencies with different stakeholders. This requires excellent 
communication and coordination skills in order to ensure that the reform is successful, and countries with lower power distance would be better at this. Another factor to consider in this analysis is that low power distance countries usually have less corruption when compared to high power distance societies (Jain and Jain 2018). This could be a factor that affects low LPI scoring countries and the transparency of their logistics operations.

A good example along this discussion would be in comparing two countries like Philippines and Finland. One would typically expect a high LPI score for the Philippines, with its excellent geographical location and its investment in good infrastructure for air and sea transport along a growing knowledge-based economy. However, the Philippines has a relatively high power distance score of 94 that can be one of the reasons for a relatively low LPI score of 2.91/5. On the other hand, a country like Finland with less geographical location privilege has a higher LPI score of 3.97/5 with all national culture dimensions that are relatively close to the Philippines except for a significant lower power distance score of 33. Indeed, there are other economic factors that contributes to this discrepancy; however, the national culture orientation could offer additional opportunity of better understanding.

\subsubsection{Uncertainty Avoidance}

Uncertainty Avoidance is a measure of how tolerable a society is with ambiguity. It is a measure of how a society deals with unknown and new situations. "Uncertainty avoiding cultures try to minimize the possibility of such situations by strict behavioral codes, laws and rules, disapproval of deviant opinions, and a belief in absolute Truth" (Hofstede, pp.11, 2011). In a high uncertainty avoidance environment, excessive 
bureaucracy or adherence to rules and formalities (sometimes referred to as red tape), especially in the public sector, is expected. This creates a lack of flexibility that would affect many of the public (and in some cases private) agencies involved in logistics and in turn negatively affect the LPI score of a country. With today's turbulent logistics environment and demand uncertainty, high uncertainty avoidance scoring countries are generally not expected to adapt well to such an environment. The logistics performance is a measure of how countries deal with constantly changing laws, situations with other countries, technology, etc. Research by (Guang \& Yang, 2015), has also shown that uncertainty avoidance has a significant negative correlation with supply chain collaboration. The best supply chains are usually agile and can react to changes successfully. Low uncertainty avoidance has been proven to have a positive effect on agile supply chain management (Santos et al., 2012). Countries that have less problems dealing with ambiguity and uncertainty can easily react to situations and tend to be more successful. Our data analysis validates these points by showing that Uncertainty Avoidance is negatively correlated with the LPI score. It should be noted that uncertainty avoidance is not the same as risk avoidance. Risk avoidance could indicate avoiding undue risks while checking the quality of products and ensuring reliability which would improve the LPI. Uncertainty avoidance is only a measure of how comfortable countries are at working in structured and unstructured environments. The paper by (Everdingen \& Waarts, 2003) on the effect of acceptance of innovation and technology by countries by using ERP as a focused example proved that uncertainty avoidance is negatively correlated with innovation acceptance. With the constantly evolving technology, uncertainty avoidance could lead to countries being left behind by the rest of the logistics 
sector. Another fact is that countries with low uncertainty avoidance are usually better at seeking out and making new relationships. This is critical in the domain of sourcing and supplier management in the context of global supply chains. This also allows the fostering of better relations with neighboring countries and since the nature of the LPI survey is measure of the perception of the logistics of the neighboring countries, this can affect the LPI.

This inverse relationship between uncertainty avoidance and logistics performance can explain some of the reasons why Hong Kong outperforms Greece in terms of LPI score. Hong Kong has a higher LPI score of 3.96 compared to Greece's 3.11. Although most of their scores on other national culture dimension are similar, Hong Kong's uncertainty avoidance score is 29 , which is much lower than the very high score of 100 for Greece.

\subsubsection{Long Term Orientation}

Long term orientation, as the name implies, is a measure of how far into the future a country is willing to plan for. It is intuitive to expect that long-term planning leads to better performance results in the future. Countries that scored higher on the LPI scores also had higher scores in the long-term orientation dimension, manifesting how this culture orientation is positively influencing logistics performance. Some of the characteristics of long term oriented societies as stated by Hofstede himself include, the possibility to change traditions and adapt to circumstances and also to learn from other countries. These characteristics would help in logistics performance and any performance in in general. Long term orientation has also been proven to have a positive correlation with effective supply chain disruption management and prevention (Kumar et al., 2015). 
(Cannon, Doney, Mullen, \& Petersen, pp.1, 2010) have also stated "Research and practice have shown that buyer-supplier relationships benefit when partners to the relationship exhibit a long-term orientation." Long term orientation has also been found to increase trust among inter organizational members and lower conflict as well (Ryu \& Moon, 2009). More long term orientation will help prevent short term mindsets in the culture of the people, which can also improve the relationships with suppliers and hence the entire supply chain and logistics of that country. As the LPI score of a country is based on the surveys answered by the eight countries dealing with that country's exports and imports, a better long term relationship between the countries should favor a better LPI score. Long term orientation can also directly affect the infrastructure and planning capability, which will in turn enhance logistics. For example, countries with visionary development and economic plans, will invest more into ports, harbors and other logistics capacities, which will improve the quality of supply chain activities. In addition, this visionary and long-term behavior will help countries in the prediction of problems and issues and thus account for them. This can help improve the reliability and quality of the supply chain, which are factors that affect the LPI score as well.

A good example of this positive relationship would be in comparing and contrasting the LPI scores of Germany and Ireland. Both counties' scores along the national culture dimensions are relatively close, except for their long-term orientations' scores. Germany scored 83, whereas Ireland scored only 24 for that dimension. One can claim that this can help us to understand (in addition to other technical and economic reasons) why Germany's LPI score is 4.19 which is higher that Ireland's 3.63 score. 


\subsubsection{Individualism}

Individualism vs Collectivism is a measure of how self-serving a culture can be. It is a measure of whether the culture promotes serving one's own interests or putting the needs of the larger community first. Countries that scored higher in Individualism would be expected to have a positive impact on the LPI score. Individualism promotes taking responsibility and independence. This promotes transparency and has a negative effect on corruption and coverups (Jain \& Jain, 2018), both of which can negatively affect logistics and the economy as well. As mentioned earlier, innovation and desire for improvement are both required to improve the quality and performance of logistics. The paper by (Prim et al., 2017) shows that Individualism has a positive effect on innovation. It mentions that when there is a culture of independence, the people have greater freedom to create and execute their ideas. Innovation and desire for improvement are both required to improve the quality and performance of logistics especially with the rapid technological advances. The work by (Rinne, Steel, \& Fairweather, 2013) proves that of all of Hofstede's dimensions, it is only individualism that has a positive effect on national level creativity. This increased creativity can allow for innovative and cost-effective solutions to problems concerning logistics. The work by (Cristian-gabriel, 2015), proves that logistics and the LPI is also improved by innovation. Furthermore, economic data shows that individualistic societies are generally more developed and place more importance on science and technology, as compared to collectivist cultures. Although collectivistic cultures may intuitively seem better for the LPI score because of the requirements for communication and coordination, the mindset of individualistic cultures allows them to conduct business with any other country, irrespective of their faith, religion, race... etc. 
as the motivation is usually monetary. This progressive mindset and way of thinking of individualistic societies are why it is expected that individualism scores positively correlate with the LPI.

A good example of the effect of Individualism is the comparison between India and Bangladesh. Both countries have a similar culture except for the Individualism dimension. India has a relatively higher Individualism score of 48 when compared to Bangladesh's 20 and this could be the reason for India's higher LPI score of 3.22 compared to Bangladesh's 2.6. 


\section{Chapter 5-CONCLUSION}

\subsection{Summary}

The purpose of this thesis was to understand the national cultural antecedents that may help explain some of the variation in logistics performance of different countries. Using secondary data from the international Logistics Performance Index (LPI) World Bank report of 2018, as well as the most recent scores from Hofstede's national culture dimension surveys, the impact of national culture on logistics performance was explored. Four of these dimensions were found to have a significant impact and a correlation with LPI scores. Specifically, Power Distance and Uncertainty Avoidance were found to have a negative correlation with LPI while Individualism as well as Long Term Orientation were both positively correlated to LPI. This cultural understanding has clear research impact and could also lead to effective and/or better logistics management. 
Table 8. Results Summary

\begin{tabular}{|c|c|c|c|c|c|c|}
\hline Dimension & Response & $\begin{array}{l}\text { Pearson's } \\
\text { Coefficient }\end{array}$ & $\begin{array}{l}\text { Correlation } \mathbf{P} \\
\text { Value }\end{array}$ & $\begin{array}{l}\text { Regression } \mathbf{P} \\
\text { Value }\end{array}$ & $\begin{array}{l}\text { Model } \\
\text { Inclusion }\end{array}$ & Result \\
\hline Power Distance & LPI Score & -.533 & 0.000 & 0.080 & Included & $\begin{array}{l}\text {-ve Significant } \\
\text { Effect }\end{array}$ \\
\hline Individualism & LPI Score & .604 & 0.000 & 0.002 & Included & $\begin{array}{l}\text { +ve Significant } \\
\text { Effect }\end{array}$ \\
\hline Masculinity & LPI Score & .008 & 0.950 & $\mathrm{~N} / \mathrm{A}$ & Not included & $\begin{array}{l}\text { No Significant } \\
\text { Effect }\end{array}$ \\
\hline Indulgence & LPI Score & .117 & 0.366 & 0.015 & Included & $\begin{array}{l}\text { No Significant } \\
\text { Effect }\end{array}$ \\
\hline $\begin{array}{l}\text { Long Term } \\
\text { Orientation }\end{array}$ & LPI Score & .418 & 0.001 & 0.000 & Included & $\begin{array}{l}\text { +ve Significant } \\
\text { Effect }\end{array}$ \\
\hline $\begin{array}{l}\text { Uncertainty } \\
\text { Avoidance }\end{array}$ & LPI Score & -.345 & .006 & .016 & Included & $\begin{array}{l}\text {-ve Significant } \\
\text { Effect }\end{array}$ \\
\hline
\end{tabular}




\subsection{Final Remarks}

From a methodological perspective, these findings imply that multi-country research on logistics performance could benefit from the inclusion of cultural factors in the research model in addition to the traditional meso and microfactors. Furthermore, this thesis will add to the growing body of research that examines how differing cultural values may affect global logistics performance. At a general level, this study provides empirical evidence suggesting the need to integrate theories of culture into logistics performance. Theories originating in economics have tended to emphasize more objective aspects of relationships, while those drawn from psychology and sociology place greater weight on interpersonal elements of exchange.

The recognition that "culture matters" has important practical implications for supply chain managers, as well as logistics practitioners. These implications are summarized as follows:

- At a strategic level, for managers and policy makers, the results show that not only capital investments can benefit the logistics performance of countries, but managers can also leverage country-level resources in a manner that optimizes logistics performance. The results also can help these managers and policy makers in better planning for how to manage country-level challenges that can hinder this performance.

- Along the same strategic level, and for countries to improve their logistics performance, reforms will be required to include several different agencies with different stakeholders. Improving communications, increasing flexibility and 
enhancing trust relationships are some examples of logistics performance targets that will depend on these reforms.

- At a tactical level, these findings are of high practical relevance due to increasing globalization. The research by (Newman \& Nollen, 1996) shows that the performance of multinational firms depends on the congruence between management practices and national culture and that one management style does not fit every culture. Logistics managers should consider national culture when planning and organizing their logistics capacities and how to decide on the best sequence of the international roll-out of their logistics resources. For example, care should be taken in assessing the cultural values and management practices in countries with high power distance if timeliness and efficiency is of high interest to the firm. Same recommendation would apply for example in planning to establish or implement innovative logistics initiatives in countries with low individualism or high uncertainty avoidance. Once the competitive priority of the firm has been set, logistics managers might identify the country with a national culture that can enhance the logistics performance required for such priority.

- At an operational level, this national culture insight can help logistics managers to adjust their communication and distribution strategies according to each country's cultural traits. For instance, in high power distance cultures, managers should allocate extra effort to ensure effective and transparent communication, while in low long term orientation countries, they should work more on improving trust in their buyer-supplier relationship. 
- At a social level, understanding the impacts of each of these cultural dimensions on the LPI can help draw importance to other deeply rooted issues. For example, power distance is found to have a negative correlation with the LPI. Power distance has also been found to have a positive correlation with corruption and crime (Husted, 1999). These revelations can provide the necessary motivation for countries to address their issues and bring about change.

In conclusion, and as a result of this study, logistics researchers and managers of multinational firms with plants around the world can better understand why logistics performance is not uniform. Overall, these results can open further research along that direction and can also guide managers in their decisions regarding where and when to locate their logistics resources.

\subsection{Future Work}

While the work in this thesis aims to be a complete as possible, there is a certain amount of research that can be applied at a later date. This research used Hofstede's model as it is the most validated and cited model of national culture. A comparison of results and literature-based discussion with other models could also be attempted to further validate or critique the Hofstede model and obtain different insights. The dimension of Masculinity was found to have no effect on the LPI in this research and was omitted. The dimension of Indulgence was found to have a partial effect on the LPI and was kept in the regression model but was not adequately discussed as the literature did not reveal any real effect of Indulgence on the LPI. Further research on this can also be done to discover the reason that Indulgence acts as a suppressor or to try and find an effect of it on the LPI. Although two methods of clustering were attempted in this 
research, they did not reveal any meaningful information and the data was found to not be suitable for clustering in these algorithms. However, there are several other clustering algorithms such as divisive agglomerative clustering, Partitioning Around Medoids clustering, etc. that can all be applied as well to try and form clusters. As the clustering was merely viewed as additional content and not the major focus of this thesis, only Kmeans and agglomerative hierarchical clustering methods were attempted. The effects of each of Hofstede's dimensions on each component of the LPI can be further analyzed and discussed in greater detail. This is not done in this thesis as the final LPI score is very close to the simple average of the scores of the components. Lastly, further research on the far-reaching effects of both national culture and LPI and other factors that could have moderating effects on the two can also be conducted as a direct relationship between these two variables has now been established with this thesis. 


\section{References}

Aharonovitz, M., Vieira, J. and Suyama, S. (2018) How logistics performance is affected by supply chain relationships. The International Journal of Logistics Management, Vol. 29(1): 284-307

Arvis, Jean-François; Ojala, Lauri; Wiederer, Christina; Shepherd, Ben; Raj, Anasuya; Dairabayeva, Karlygash; Kiiski, Tuomas. (2018) Connecting to Compete 2018 : Trade Logistics in the Global Economy. World Bank, Washington, DC. (C) World Bank. https://openknowledge.worldbank.org/handle/10986/29971 License: CC BY 3.0 IGO

Barry Shore (2001) "Information Sharing in Global Supply Chain Systems.” Journal of Global Information Technology Management, 4:3, 27-50

Beugelsdijk, Sjoerd, Robbert Maseland, and André van Hoorn. 2015. “Are Scores on Hofstede's Dimensions of National Culture Stable over Time? A Cohort Analysis." Global Strategy Journal 5(3): 223-40.

Bowersox, D.J., Closs, D.J., Stank, T.P. and Keller, S.B. (2000), How supply chain competency leads to business success. Supply Chain Management Review, 4(4): 708

Brewer, P.C. and Speh, T.W. (2000) Using the Balanced Scorecard to Measure Supply Chain Performance. Journal of Business Logistic, 21, 75-93

Cannon, J. P., Doney, P. M., Mullen, M. R., \& Petersen, K. J. (2010). Building long-term orientation in buyer-supplier relationships: The moderating role of culture. Journal 
of Operations Management, 28(6), 506-521.

https://doi.org/10.1016/j.jom.2010.02.002

Conceição, S. and Quintão R. (2004), Evaluation of the logistic performance of Brazil's soft drink supply chain. Gestão \& Produção, Vol. 11(3): 441-453,

Civelek, Mustafa Emre, Nagehan Uca, and Murat Cemberci. 2015. “The Mediator Effect Of Logistics Performance Index On The Relation Between Global Competitiveness Index.” European Scientific Journal May 2015 edition vol.11, No.13

Chen, I.J. and Paulraj, A. (2004), Towards a theory of supply chain management: the constructs and measurements. Journal of Operations Management, Vol. 22(2): 11950.

Chinese Culture Connection (1987). Chinese values and the search for culture-free dimensions of culture. Journal of Cross-Cultural Psychology, 18, 143-174.

Council of Supply Chain Management Professionals (2007), "Supply chain management and logistics management definitions", available at: www.cscmp.org/Website/AboutCSCMP/Definitions/Definitions.asp

Cox, P. L., Friedman, B. A., \& Tribunella, T. (2011). Relationships among Cultural Dimensions , National Gross Domestic Product, and Environmental Sustainability State University of New York at Oswego Süleyman Şah Üniversitesi. Journal of Applied Business and Economics, 12(2008), 46-56.

Enslow, B., Fontanella, J., Harrity, C. and Higgins L. (2005), By the Numbers: Logistics, Houston, TX: American Productivity and Quality Center.

Everdingen, Y. M. V. A. N., \& Waarts, E. (2003). The Effect of National Culture on, 
(2000), 217-232.

Figlio, D., Giuliano, P., Özek, U., \& Sapienza, P. (2017). Long-Term Orientation and Educational Performance. National Bureau of Economic Research Working Paper Series, No. 22541, 1-73. https://doi.org/10.3386/w22541

Fawcett and Cooper (1998). "Logistics Performance Measurement and Customer Success." Industrial Marketing Management 27, 341-357

Flammer, C and Bansal, P (2017) Does a long-term orientation create value? Evidence from a regression discontinuity. Strategic Management Journal 38(9): 1827-1847.

Frost, Jim. (2018) How To Interpret R-Squared in Regression Analysis. Statistics By Jim, 12 Nov. 2018, https://statisticsbyjim.com/regression/interpret-r-squared-regression

Fugate, Brian \& T. Mentzer Ph.D, John \& Stank, Theodore. (2010). Logistics Performance: Efficiency, Effectiveness, and Differentiation. Journal of Business Logistics. $31.43-62$.

Ghemawat, P. \& Reiche, S. (2011). National cultural differences and multinational business. Globalization note series, 1-15.

Green Jr, K., Whitten, D and Inman M. (2008), The impact of logistics performance on organizational performance in a supply chain context. Supply Chain Management: An International Journal 13(4): 317-327

Griffis, Stanley E., Thomas J. Goldsby, Martha Cooper, and David J. Closs (2007), Aligning Logistics Performance Measures to the Information Needs of the Firm. Journal of Business Logistics, Vol. 28(2): 35-56

Guang, W., \& Yang, Z. (2015). The effect of uncertainty avoidance and social trust on 
supply chain collaboration. Journal of Business Research, 68(5), 911-918. https://doi.org/10.1016/j.jbusres.2014.09.017

Guner, S., \& Coskun, E. (2012). Comparison of Impacts of Economic and Social Factors on Countries' Logistics Performances: A Study with 26 OECD Countries. Research in Logistics \& Production, 2(4), 329-343.

Hajiesmaeli, A., Rahimi. M., Jaberi, E. and Hosseini A., (2016) Studying the influence of Logisitcs on organizational perofrmance through supply chain strategy: Case study in Goldiran Electronics Co. Intenrational Journal of Economics and Management Engineering, Vol. 10(4): 1065-1073

Hill, J.A., Eckerd, S., Wilson, D., Greer, B. (2009). The effect of unethical behavior on trust in a buyer-supplier relationship: the mediating role of psychological contract violation. Journal of Operations Management 27 (4): 281-293

Hofstede, G. (2011). Dimensionalizing Cultures: The Hofstede Model in Context. Online Readings in Psychology and Culture, 2(1).

Hofstede, G. (2015, November/December). Retrieved from https://geerthofstede.com/research-and-vsm/dimension-data-matrix/

Ireland, R.D., Webb, J.W. (2007). A multi-theoretic perspective on trust and power in strategic supply chains. Journal of Operations Management, 25 (2): 482- 497.

Jain, S. S., \& Jain, S. P. (2018). Power distance belief and preference for transparency. Journal of Business Research, 89(April), 135-142. https://doi.org/10.1016/j.jbusres.2018.04.016 
Kouvelis, P., Chambers, C., Wang, H. (2006). Supply chain management research and production and operations management: review, trends, and opportunities. Production \& Operations Management, 15(3) 449-469

Kumar, S., Liu, J., and Demirag, O. (2016). National culture's impact on effectiveness of supply chain disruption management. Journal of Applied Business and Economics, 17(4). 11-29.

Khatri, N. (2009). Consequences of Power Distance Orientation in Organisations. Vision: The Journal of Business Perspective, 13(1), 1-9. https://doi.org/10.1177/097226290901300101

Kenneth, W., Jr, G., Whitten, D., \& Inman, R. A. (2005). The impact of logistics performance on organizational performance in a supply chain context. Supply Chain Management (2008), 13(4), 317-327. https://doi.org/10.1108/13598540810882206

Lai, K. H., Ngai, E. W. T., \& Cheng, T. C. E. (2004). An empirical study of supply chain performance in transport logistics. International Journal of Production Economics, 87(3), 321-331. https://doi.org/10.1016/j.ijpe.2003.08.002

Laskowska-Rutkowska, A. (2009). The impact of national and organizational culture on the cooperation of firms-a supply chain perspective. Journal of Intercultural Management, 1(2), 5-16.

Martí, L., Puertas, R., \& García, L. (2014). The importance of the Logistics Performance Index in international trade. Applied Economics, 46(24), 2982-2992. https://doi.org/10.1080/00036846.2014.916394

Matusitz, J., \& Musambira, G. (2013). Power distance, uncertainty avoidance, and 
technology: Analyzing Hofstede's dimensions and human development indicators. Journal of Technology in Human Services, 31(1), 42-60.

https://doi.org/10.1080/15228835.2012.738561

Merritt, A. (2000). Culture in the cockpit: Do Hofstede's dimensions replicate? Journal of Cross-Cultural Psychology, 31(3), 283-301. https://doi.org/10.1177/0022022100031003001

Moons, P., Waeyenbergh, G. and Pintelon, L. (2019), Measuring the logistics performance of internal hospital supply chains - A literature study. Omega, Vol. (82): $205-217$

Newman, K. L., \& Nollen, S. D. (1996). Culture and congruence: The fit between management practices and national culture. Journal of International Business Studies, 27(4), 753-779. doi: 10.1057/palgrave.jibs. 8490152

Pagell, M., Katz, J. P., \& Sheu, C. (2005). The importance of national culture in operations management research. International Journal of Operations \& Production Management, 25(4), 371-394. https://doi.org/10.1108/01443570510585552

Palmatier, R.W., Dant, R.P., Grewal, D., Evans, K.R. (2006). Factors influencing effectiveness of relationship marketing: a meta-analysis. Journal of Marketing, 70 (4): 136-153.

Prim, A. L., Filho, L. S., Zamur, G. A. C., \& DI Serio, L. C. (2017). The relationship between National Culture Dimensions and Degree of Innovation. International Journal of Innovation Management, 21(01), 1730001(22 pages). https://doi.org/10.1142/S136391961730001X 
Rinne, T., Steel, G. D., \& Fairweather, J. (2013). The Role of Hofstede's Individualism in National-Level Creativity. Creativity Research Journal, 25(1), 129-136. https://doi.org/10.1080/10400419.2013.752293

Ryu, S., \& Moon, C. W. (2009). Long-Term Orientation As A Determinant Of Relationship Quality Between Channel Members. International Business and Economics Research Journal, 8(11), 1-10.

Santos, F. C. A., Fogaça, D. R., de Souza, R. Q., Marinho Toledo, R. C., \& Guimarães Gandra, M. V. (2012). Cultural Dimensions of Agile Supply Chain Management. In POMS 23rd Annual Conference. Retrieved from http://www.dt.co.kr/contents.html?article_no=2012071302010531749001

Shang, K and Marlow P (2007), The effects of logistics competency on performance. Journal of International Logistics and Trade, Vol 5(2): 45-66.

Schramm-Klein, H. and Morschett, D. (2006), The relationship between marketing performance, logistics performance and company performance for retail companies. International Review of Retail, Distribution and Consumer Research, Vol. 16 (2): 277-96.

Schwartz, S. (2008). Cultural Value Orientations: Nature \& Implications of National Differences.

Shore, B. (2001). Information sharing in global supply chain systems. Journal of Global Information Technology Management, 4(3), 27-50. https://doi.org/10.1080/1097198X.2001.10856306

Soares, A. M., Farhangmehr, M., \& Shoham, A. (2007). Hofstede's dimensions of culture 
in international marketing studies. Journal of Business Research, 60(3), 277-284. https://doi.org/10.1016/j.jbusres.2006.10.018

Stringfellow, A., Teagarden, M.B., Nie, W., (2008). Invisible costs in offshoring services work, Journal of Operations Management. 26 (2): 164-179.

Ülgen, V., and Forslund, H. (2015) Logistics performance management in textiles supply chains: best-practice and barriers. International Journal of Productivity and Performance Management, Vol. 64(1): 52-75.

Strychalska-rudzewicz, A. (2016). The Impact of National Culture on the Level of Innovation, 8(1), 121-145. https://doi.org/10.1515/joim-2016-0006

Wang, M. (2018) Impacts of supply chain uncertainty and risk on the logistics performance. Asia Pacific Journal of Marketing and Logistics, Vol. 30(3):.689-704

Waters, D. (2003). Logistics: An Introduction to Supply Chain Management. Supply Chain Management An International Journal, 364.

Wong, Christina W.Y., Cristina Sancha, and Cristina Gimenez Thomsen. 2017. “A National Culture Perspective in the Efficacy of Supply Chain Integration Practices.” International Journal of Production Economics 193 (2017) 554-565

Ying, F., Tookey, J. and Seadon, J. (2018) Measuring the invisible: A key performance indicator for managing construction logistics performance. Benchmarking: An International Journal, Vol. 25(6): 1921-1934. 


\section{Appendices}

\section{A. Dataset Used}

\begin{tabular}{|c|c|c|c|c|c|c|c|c|c|c|c|c|c|c|c|c|}
\hline Country & $\begin{array}{l}\text { LPI } \\
\text { Ran } \\
\mathbf{k} \\
\end{array}$ & $\begin{array}{l}\text { LPI } \\
\text { Scor } \\
\text { e }\end{array}$ & $\begin{array}{l}\text { Cus } \\
\text { tom } \\
\text { s }\end{array}$ & $\begin{array}{l}\text { Infras } \\
\text { tructu } \\
\text { re }\end{array}$ & $\begin{array}{l}\text { Internatio } \\
\text { nal } \\
\text { shipments }\end{array}$ & $\begin{array}{l}\text { Logistics } \\
\text { quality and } \\
\text { competence }\end{array}$ & $\begin{array}{l}\text { Tracking } \\
\text { and } \\
\text { tracing }\end{array}$ & $\begin{array}{l}\text { Tim } \\
\text { eline } \\
\text { ss } \\
\end{array}$ & $\begin{array}{l}\text { Power } \\
\text { Distan } \\
\text { ce }\end{array}$ & $\begin{array}{l}\text { Indivi } \\
\text { dualis } \\
\text { m } \\
\end{array}$ & $\begin{array}{l}\text { Masc } \\
\text { ulinit } \\
\text { y } \\
\end{array}$ & $\begin{array}{l}\text { Uncertaint } \\
\mathbf{y} \\
\text { Avoidance } \\
\end{array}$ & $\begin{array}{l}\text { Long } \\
\text { Term } \\
\text { Orientatio } \\
\text { n } \\
\end{array}$ & $\begin{array}{l}\text { Indu } \\
\text { lgenc } \\
\text { e } \\
\end{array}$ & $\begin{array}{l}\text { Lat } \\
\text { itud } \\
\text { e }\end{array}$ & $\begin{array}{l}\text { Lon } \\
\text { gitu } \\
\text { de } \\
\end{array}$ \\
\hline Argentina & 62 & 2.93 & 2.49 & 2.81 & 2.91 & 2.82 & 3.13 & 3.41 & 49 & 46 & 56 & 86 & 20 & 62 & $\begin{array}{r}33 . \\
166 \\
\end{array}$ & $\begin{array}{r}64.3 \\
1 \\
\end{array}$ \\
\hline Australia & 19 & 3.77 & 3.76 & 3.92 & 3.4 & 3.76 & 3.83 & 4 & 38 & 90 & 61 & 51 & 21 & 71 & $\begin{array}{r}- \\
24 . \\
578 \\
\end{array}$ & $\begin{array}{r}133 . \\
582 \\
\end{array}$ \\
\hline Austria & 8 & 3.99 & 3.71 & 4.07 & 3.78 & 4.04 & 4.13 & 4.22 & 11 & 55 & 79 & 70 & 60 & 63 & $\begin{array}{r}47 . \\
65\end{array}$ & $\begin{array}{r}14.7 \\
05\end{array}$ \\
\hline $\begin{array}{l}\text { Banglade } \\
\text { sh }\end{array}$ & 100 & 2.6 & 2.33 & 2.36 & 2.66 & 2.56 & 2.67 & 2.97 & 80 & 20 & 55 & 60 & 47 & 20 & $\begin{array}{r}24 . \\
598 \\
\end{array}$ & $\begin{array}{r}90.1 \\
963 \\
\end{array}$ \\
\hline Belgium & 4 & 4.05 & 3.74 & 4.03 & 3.97 & 4.1 & 4.11 & 4.4 & 65 & 75 & 54 & 94 & 82 & 57 & $\begin{array}{r}50 . \\
674 \\
5 \\
\end{array}$ & $\begin{array}{r}4.45 \\
88 \\
\end{array}$ \\
\hline Brazil & 56 & 3.02 & 2.52 & 2.99 & 2.89 & 3.1 & 3.17 & 3.47 & 69 & 38 & 49 & 76 & 44 & 59 & $\begin{array}{r}- \\
11 . \\
694 \\
\end{array}$ & $\begin{array}{r}- \\
48.9 \\
78 \\
\end{array}$ \\
\hline Bulgaria & 57 & 3 & 2.77 & 2.71 & 3.16 & 2.96 & 2.93 & 3.43 & 70 & 30 & 40 & 85 & 69 & 16 & $\begin{array}{r}42 . \\
625 \\
\end{array}$ & $\begin{array}{r}24.5 \\
21 \\
\end{array}$ \\
\hline Chile & 40 & 3.28 & 3.23 & 3.09 & 3.24 & 3.09 & 3.3 & 3.73 & 63 & 23 & 28 & 86 & 31 & 68 & $\begin{array}{r}- \\
23 . \\
176^{-}\end{array}$ & $\begin{array}{r}- \\
69.2 \\
01 \\
\end{array}$ \\
\hline China & 27 & 3.6 & 3.28 & 3.73 & 3.57 & 3.58 & 3.63 & 3.86 & 80 & 20 & 66 & 30 & 87 & 24 & $\begin{array}{r}35 . \\
175 \\
3 \\
\end{array}$ & $\begin{array}{r}99.3 \\
877 \\
\end{array}$ \\
\hline Colombia & 71 & 2.81 & 2.5 & 2.58 & 2.93 & 2.79 & 2.84 & 3.17 & 67 & 13 & 64 & 80 & 13 & 83 & $\begin{array}{r}3.7 \\
94\end{array}$ & $\begin{array}{r}- \\
73.6 \\
06\end{array}$ \\
\hline Croatia & 48 & 3.12 & 3.01 & 3.02 & 2.99 & 3.1 & 3.08 & 3.51 & 73 & 33 & 40 & 80 & 58 & 33 & $\begin{array}{r}45 . \\
754\end{array}$ & $\begin{array}{r}16.3 \\
85 \\
\end{array}$ \\
\hline $\begin{array}{l}\text { Czech } \\
\text { Republic }\end{array}$ & 26 & 3.62 & 3.34 & 3.38 & 3.65 & 3.65 & 3.68 & 3.98 & 57 & 58 & 57 & 74 & 70 & 29 & $\begin{array}{r}49 . \\
848 \\
\end{array}$ & $\begin{array}{r}15.2 \\
812 \\
\end{array}$ \\
\hline Denmark & 11 & 3.92 & 3.88 & 3.89 & 3.59 & 3.98 & 3.94 & 4.26 & 18 & 74 & 16 & 23 & 35 & 70 & $\begin{array}{r}56 . \\
113 \\
\end{array}$ & $\begin{array}{r}9.09 \\
6 \\
\end{array}$ \\
\hline
\end{tabular}




\begin{tabular}{|c|c|c|c|c|c|c|c|c|c|c|c|c|c|c|c|c|}
\hline $\begin{array}{l}\text { El } \\
\text { Salvador }\end{array}$ & 88 & 2.66 & 2.4 & 2.31 & 2.79 & 2.67 & 2.63 & 3.1 & 66 & 19 & 40 & 94 & 20 & 89 & $\begin{array}{r}13 . \\
848\end{array}$ & $\begin{array}{r}89.2 \\
29\end{array}$ \\
\hline Finland & 12 & 3.92 & 3.89 & 3.95 & 3.56 & 3.88 & 4.1 & 4.17 & 33 & 63 & 26 & 59 & 38 & 57 & $\begin{array}{r}62 . \\
716\end{array}$ & $\begin{array}{r}26.1 \\
92\end{array}$ \\
\hline France & 15 & 3.86 & 3.63 & 4 & 3.6 & 3.82 & 3.99 & 4.17 & 68 & 71 & 43 & 86 & 63 & 48 & $\begin{array}{r}46 . \\
656\end{array}$ & $\begin{array}{r}2.54 \\
3\end{array}$ \\
\hline Germany & 1 & 4.19 & 4.09 & 4.38 & 3.83 & 4.26 & 4.22 & 4.4 & 35 & 67 & 66 & 65 & 83 & 40 & $\begin{array}{r}51 . \\
381 \\
9\end{array}$ & $\begin{array}{r}9.98 \\
77\end{array}$ \\
\hline Greece & 44 & 3.19 & 2.88 & 3.19 & 3.13 & 3.02 & 3.25 & 3.67 & 60 & 35 & 57 & 100 & 45 & 50 & $\begin{array}{r}39 . \\
787\end{array}$ & $\begin{array}{r}21.6 \\
17\end{array}$ \\
\hline $\begin{array}{l}\text { Hong } \\
\text { Kong, } \\
\text { China }\end{array}$ & 9 & 3.96 & 3.85 & 4.02 & 3.85 & 3.94 & 3.95 & 4.18 & 68 & 25 & 57 & 29 & 61 & 17 & $\begin{array}{r}22 . \\
436\end{array}$ & $\begin{array}{r}114 . \\
099\end{array}$ \\
\hline Hungary & 32 & 3.41 & 3.18 & 3.31 & 3.29 & 3.27 & 3.61 & 3.82 & 46 & 80 & 88 & 82 & 58 & 31 & $\begin{array}{r}47 . \\
174\end{array}$ & $\begin{array}{r}19.6 \\
18\end{array}$ \\
\hline India & 42 & 3.22 & 2.97 & 3.01 & 3.24 & 3.18 & 3.33 & 3.57 & 77 & 48 & 56 & 40 & 51 & 26 & $\begin{array}{r}22 . \\
741\end{array}$ & $\begin{array}{r}78.2 \\
36\end{array}$ \\
\hline Indonesia & 51 & 3.08 & 2.69 & 2.81 & 3.08 & 3.07 & 3.23 & 3.59 & 78 & 14 & 46 & 48 & 62 & 38 & $\begin{array}{r}0.7 \\
39\end{array}$ & $\begin{array}{r}114 . \\
045\end{array}$ \\
\hline
\end{tabular}




\begin{tabular}{|c|c|c|c|c|c|c|c|c|c|c|c|c|c|c|c|c|}
\hline Rep. & & & & & & & & & & & & & & & & \\
\hline Ireland & 25 & 3.63 & 3.45 & 3.5 & 3.53 & 3.69 & 3.79 & 3.85 & 28 & 70 & 68 & 35 & 24 & 65 & $\begin{array}{r}53 . \\
214 \\
\end{array}$ & $\begin{array}{r}7.58 \\
8 \\
\end{array}$ \\
\hline Italy & 21 & 3.73 & 3.44 & 3.82 & 3.55 & 3.68 & 3.84 & 4.09 & 50 & 76 & 70 & 75 & 61 & 30 & $\begin{array}{r}44 . \\
371 \\
3 \\
\end{array}$ & $\begin{array}{r}11.1 \\
084 \\
\end{array}$ \\
\hline Japan & 7 & 3.99 & 3.91 & 4.19 & 3.61 & 4.03 & 4.03 & 4.24 & 54 & 46 & 95 & 92 & 88 & 42 & $\begin{array}{r}35 . \\
962\end{array}$ & $\begin{array}{r}137 . \\
855\end{array}$ \\
\hline $\begin{array}{l}\text { Korea, } \\
\text { Rep. }\end{array}$ & 23 & 3.65 & 3.43 & 3.75 & 3.43 & 3.63 & 3.75 & 3.96 & 60 & 18 & 39 & 85 & 100 & 29 & $\begin{array}{r}36 . \\
338 \\
\end{array}$ & $\begin{array}{r}128 . \\
16 \\
\end{array}$ \\
\hline Latvia & 55 & 3.02 & 2.93 & 3.03 & 2.97 & 2.92 & 3.06 & 3.25 & 44 & 70 & 9 & 63 & 69 & 13 & $\begin{array}{r}57 . \\
017 \\
\end{array}$ & $\begin{array}{r}25.0 \\
173 \\
\end{array}$ \\
\hline Lithuania & 43 & 3.2 & 3.02 & 3 & 3.03 & 3.1 & 3.25 & 3.78 & 42 & 60 & 19 & 65 & 82 & 16 & $\begin{array}{r}55 . \\
342 \\
\end{array}$ & $\begin{array}{r}24.2 \\
3 \\
\end{array}$ \\
\hline $\begin{array}{l}\text { Luxembo } \\
\text { urg }\end{array}$ & 16 & 3.84 & 3.67 & 3.84 & 3.68 & 3.83 & 3.78 & 4.27 & 40 & 60 & 50 & 70 & 64 & 56 & $\begin{array}{r}49 . \\
671 \\
\end{array}$ & $\begin{array}{r}6.11 \\
3 \\
\end{array}$ \\
\hline Malaysia & 35 & 3.34 & 3.06 & 3.3 & 3.43 & 3.34 & 3.32 & 3.6 & 100 & 26 & 50 & 36 & 41 & 57 & $\begin{array}{r}4.4 \\
16 \\
\end{array}$ & $\begin{array}{r}102 . \\
099 \\
\end{array}$ \\
\hline Malta & 61 & 2.94 & 2.77 & 2.95 & 2.91 & 2.85 & 2.95 & 3.24 & 56 & 59 & 47 & 96 & 47 & 66 & $\begin{array}{r}35 . \\
884 \\
\end{array}$ & $\begin{array}{r}14.4 \\
46 \\
\end{array}$ \\
\hline Mexico & 53 & 3.08 & 2.78 & 2.9 & 3.09 & 3.06 & 3.14 & 3.49 & 81 & 30 & 69 & 82 & 24 & 97 & $\begin{array}{r}22 . \\
925 \\
\end{array}$ & $\begin{array}{r}- \\
101 . \\
68 \\
\end{array}$ \\
\hline Morocco & 87 & 2.67 & 2.36 & 2.58 & 2.8 & 2.59 & 2.57 & 3.09 & 70 & 46 & 53 & 68 & 14 & 25 & $\begin{array}{r}31 . \\
129 \\
\end{array}$ & $\begin{array}{r}- \\
7.35 \\
5 \\
\end{array}$ \\
\hline $\begin{array}{l}\text { Netherlan } \\
\text { ds }\end{array}$ & 2 & 4.07 & 3.97 & 4.23 & 3.76 & 4.12 & 4.08 & 4.3 & 38 & 80 & 14 & 53 & 67 & 68 & $\begin{array}{r}52 . \\
170 \\
4 \\
\end{array}$ & $\begin{array}{r}5.01 \\
02 \\
\end{array}$ \\
\hline $\begin{array}{l}\text { New } \\
\text { Zealand }\end{array}$ & 22 & 3.68 & 3.58 & 3.79 & 3.27 & 3.69 & 3.73 & 4.1 & 22 & 79 & 58 & 49 & 33 & 75 & $\begin{array}{r}42 . \\
558 \\
\end{array}$ & $\begin{array}{r}172 . \\
377 \\
\end{array}$ \\
\hline Norway & 20 & 3.74 & 3.62 & 3.84 & 3.48 & 3.75 & 3.83 & 3.96 & 31 & 69 & 8 & 50 & 35 & 55 & $\begin{array}{r}61 . \\
370 \\
1\end{array}$ & $\begin{array}{r}9.30 \\
31\end{array}$ \\
\hline Pakistan & 95 & 2.64 & 2.41 & 2.43 & 2.79 & 2.69 & 2.52 & 2.93 & 55 & 14 & 50 & 70 & 50 & 0 & $\begin{array}{r}28 . \\
185 \\
4 \\
\end{array}$ & $\begin{array}{r}66.6 \\
429 \\
\end{array}$ \\
\hline Peru & 74 & 2.78 & 2.59 & 2.46 & 2.88 & 2.62 & 2.72 & 3.36 & 64 & 16 & 42 & 87 & 25 & 46 & $\begin{array}{r}12 \\
664\end{array}$ & $\begin{array}{r}72.9 \\
8 \\
\end{array}$ \\
\hline $\begin{array}{l}\text { Philippin } \\
\text { es }\end{array}$ & 64 & 2.91 & 2.62 & 2.67 & 3.2 & 2.8 & 3.01 & 3.11 & 94 & 32 & 64 & 44 & 27 & 42 & $\begin{array}{r}17 . \\
181 \\
\end{array}$ & $\begin{array}{r}121 . \\
256 \\
\end{array}$ \\
\hline
\end{tabular}




\begin{tabular}{|c|c|c|c|c|c|c|c|c|c|c|c|c|c|c|c|c|}
\hline Poland & 31 & 3.5 & 3.26 & 3.17 & 3.57 & 3.49 & 3.49 & 3.94 & 68 & 60 & 64 & 93 & 38 & 29 & $\begin{array}{r}52 . \\
442 \\
\end{array}$ & $\begin{array}{r}19.7 \\
2 \\
\end{array}$ \\
\hline Portugal & 28 & 3.56 & 3.24 & 3.23 & 3.59 & 3.54 & 3.69 & 4.03 & 63 & 27 & 31 & 99 & 28 & 33 & $\begin{array}{r}40 . \\
957\end{array}$ & $\begin{array}{r}7.93 \\
73 \\
\end{array}$ \\
\hline Romania & 50 & 3.1 & 2.73 & 2.86 & 3.15 & 3.01 & 3.19 & 3.61 & 90 & 30 & 42 & 90 & 52 & 20 & $\begin{array}{r}45 . \\
933 \\
\end{array}$ & $\begin{array}{r}25.1 \\
19 \\
\end{array}$ \\
\hline $\begin{array}{l}\text { Russian } \\
\text { Federatio } \\
\mathrm{n}\end{array}$ & 85 & 2.69 & 2.25 & 2.64 & 2.59 & 2.74 & 2.67 & 3.23 & 93 & 39 & 36 & 95 & 81 & 20 & $\begin{array}{r}64 . \\
736 \\
\end{array}$ & $\begin{array}{r}104 . \\
062 \\
\end{array}$ \\
\hline Serbia & 68 & 2.83 & 2.53 & 2.59 & 2.89 & 2.78 & 2.86 & 3.32 & 86 & 25 & 43 & 92 & 52 & 28 & $\begin{array}{r}44 . \\
021 \\
\end{array}$ & $\begin{array}{r}20.6 \\
99 \\
\end{array}$ \\
\hline $\begin{array}{l}\text { Singapor } \\
\mathrm{e}\end{array}$ & 5 & 4.05 & 4 & 4.14 & 3.72 & 4.08 & 4.05 & 4.34 & 74 & 20 & 48 & 8 & 72 & 46 & $\begin{array}{r}1.3 \\
64 \\
\end{array}$ & $\begin{array}{r}103 . \\
81 \\
\end{array}$ \\
\hline $\begin{array}{l}\text { Slovak } \\
\text { Republic }\end{array}$ & 47 & 3.14 & 2.94 & 3.09 & 3.19 & 3.13 & 3.02 & 3.45 & 100 & 52 & 100 & 51 & 77 & 28 & $\begin{array}{r}48 . \\
859 \\
5\end{array}$ & $\begin{array}{r}19.4 \\
434\end{array}$ \\
\hline Slovenia & 39 & 3.29 & 3.21 & 3.25 & 3.16 & 3.17 & 3.3 & 3.65 & 71 & 27 & 19 & 88 & 49 & 48 & $\begin{array}{r}46 . \\
037 \\
\end{array}$ & $\begin{array}{r}14.5 \\
34 \\
\end{array}$ \\
\hline Spain & 18 & 3.78 & 3.57 & 3.79 & 3.72 & 3.78 & 3.78 & 4.04 & 57 & 51 & 42 & 86 & 48 & 44 & $\begin{array}{r}40 . \\
617\end{array}$ & $\begin{array}{r}3.38 \\
8 \\
\end{array}$ \\
\hline Sweden & 3 & 4.07 & 3.95 & 4.22 & 3.88 & 4.04 & 4.02 & 4.32 & 31 & 71 & 5 & 29 & 53 & 78 & $\begin{array}{r}66 . \\
218 \\
8 \\
\end{array}$ & 19 \\
\hline $\begin{array}{l}\text { Switzerla } \\
\text { nd }\end{array}$ & 13 & 3.91 & 3.75 & 4.07 & 3.57 & 3.92 & 4.02 & 4.2 & 34 & 68 & 70 & 58 & 74 & 66 & $\begin{array}{r}46 . \\
779 \\
4\end{array}$ & $\begin{array}{r}8.03 \\
29 \\
\end{array}$ \\
\hline Taiwan & 24 & 3.65 & 3.42 & 3.67 & 3.54 & 3.68 & 3.67 & 3.93 & 58 & 17 & 45 & 69 & 93 & 49 & $\begin{array}{r}23 . \\
513 \\
\end{array}$ & $\begin{array}{r}120 . \\
797 \\
\end{array}$ \\
\hline Thailand & 34 & 3.36 & 3.13 & 3.17 & 3.4 & 3.29 & 3.38 & 3.75 & 64 & 20 & 34 & 64 & 32 & 45 & $\begin{array}{r}15 . \\
688 \\
\end{array}$ & $\begin{array}{r}100 . \\
845 \\
\end{array}$ \\
\hline $\begin{array}{l}\text { Trinidad } \\
\text { and } \\
\text { Tobago }\end{array}$ & 127 & 2.41 & 2.4 & 2.36 & 2.46 & 2.28 & 2.27 & 2.65 & 47 & 16 & 58 & 55 & 13 & 80 & $\begin{array}{r}10 . \\
448\end{array}$ & $\begin{array}{r}61 . \overline{-} \\
57\end{array}$ \\
\hline Turkey & 37 & 3.29 & 2.94 & 3.36 & 3.19 & 3.23 & 3.37 & 3.68 & 66 & 37 & 45 & 85 & 46 & 49 & $\begin{array}{r}39 . \\
144 \\
\end{array}$ & $\begin{array}{r}34.1 \\
88 \\
\end{array}$ \\
\hline $\begin{array}{l}\text { United } \\
\text { Kingdom }\end{array}$ & 6 & 4.01 & 3.85 & 4.09 & 3.69 & 4.04 & 4.1 & 4.32 & 35 & 89 & 66 & 35 & 51 & 69 & $\begin{array}{r}52 . \\
289\end{array}$ & $\begin{array}{r}1.25 \\
9\end{array}$ \\
\hline $\begin{array}{l}\text { United } \\
\text { States }\end{array}$ & 10 & 3.92 & 3.76 & 4.1 & 3.54 & 3.93 & 4.13 & 4.14 & 40 & 91 & 62 & 46 & 26 & 68 & $\begin{array}{r}40 . \\
079 \\
2 \\
\end{array}$ & $\begin{array}{r}- \\
98.8 \\
164 \\
\end{array}$ \\
\hline Uruguay & 75 & 2.78 & 2.6 & 2.57 & 2.78 & 2.79 & 2.83 & 3.1 & 61 & 36 & 38 & 98 & 26 & 53 & 32. & 56.2 \\
\hline
\end{tabular}




\begin{tabular}{|c|c|c|c|c|c|c|c|c|c|c|c|c|c|c|c|c|}
\hline & & & & & & & & & & & & & & & 948 & 49 \\
\hline $\begin{array}{l}\text { Venezuel } \\
\text { a, RB }\end{array}$ & 135 & 2.37 & 1.94 & 2.24 & 2.49 & 2.32 & 2.44 & 2.74 & 81 & 12 & 73 & 76 & 16 & 100 & $\begin{array}{r}6.9 \\
83\end{array}$ & $\begin{array}{r}- \\
64.5 \\
88 \\
\end{array}$ \\
\hline Vietnam & 45 & 3.16 & 2.86 & 2.92 & 3.15 & 3.17 & 3.23 & 3.6 & 70 & 20 & 40 & 30 & 57 & 35 & $\begin{array}{r}21 . \\
75\end{array}$ & $\begin{array}{r}105 \\
373\end{array}$ \\
\hline
\end{tabular}




\section{B. Tableau Clustering}

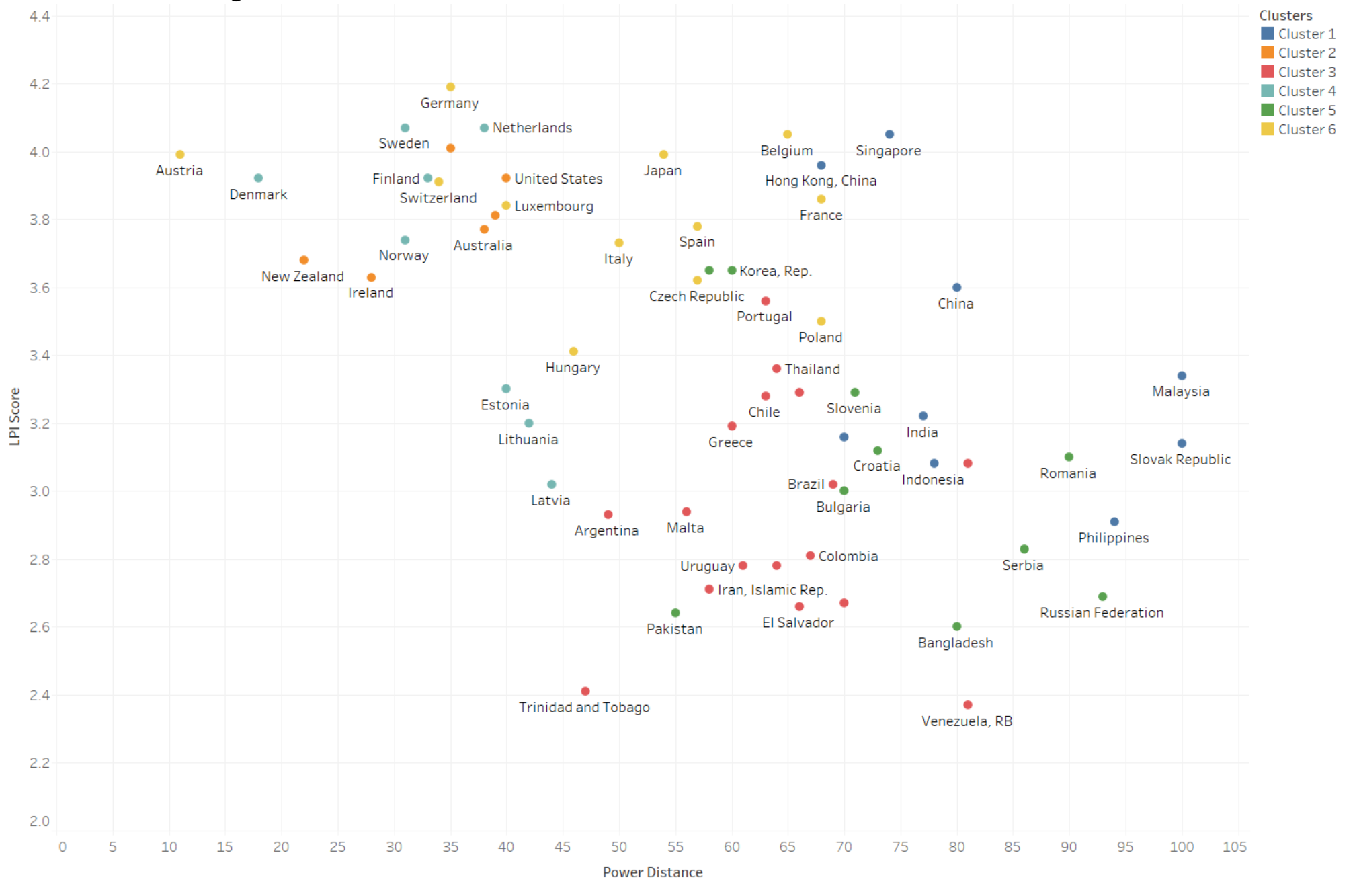


C. Map sized with Power Distance

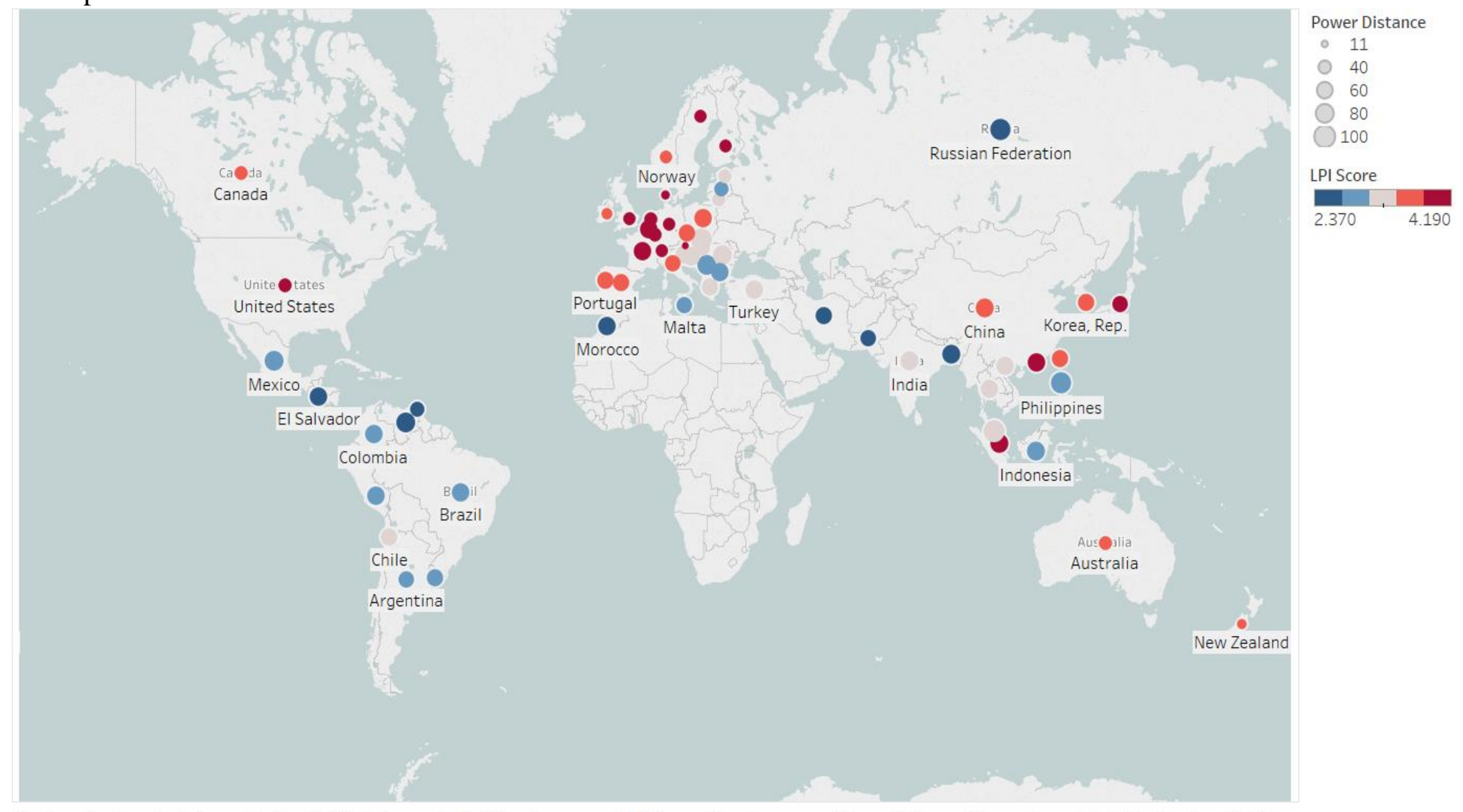

Map based on Longitude (generated) and Latitude (generated). Color shows sum of LPI Score. Size shows sum of Power Distance. The marks are labeled by Country. Details are shown for Country. 
D. Map sized with Individualism

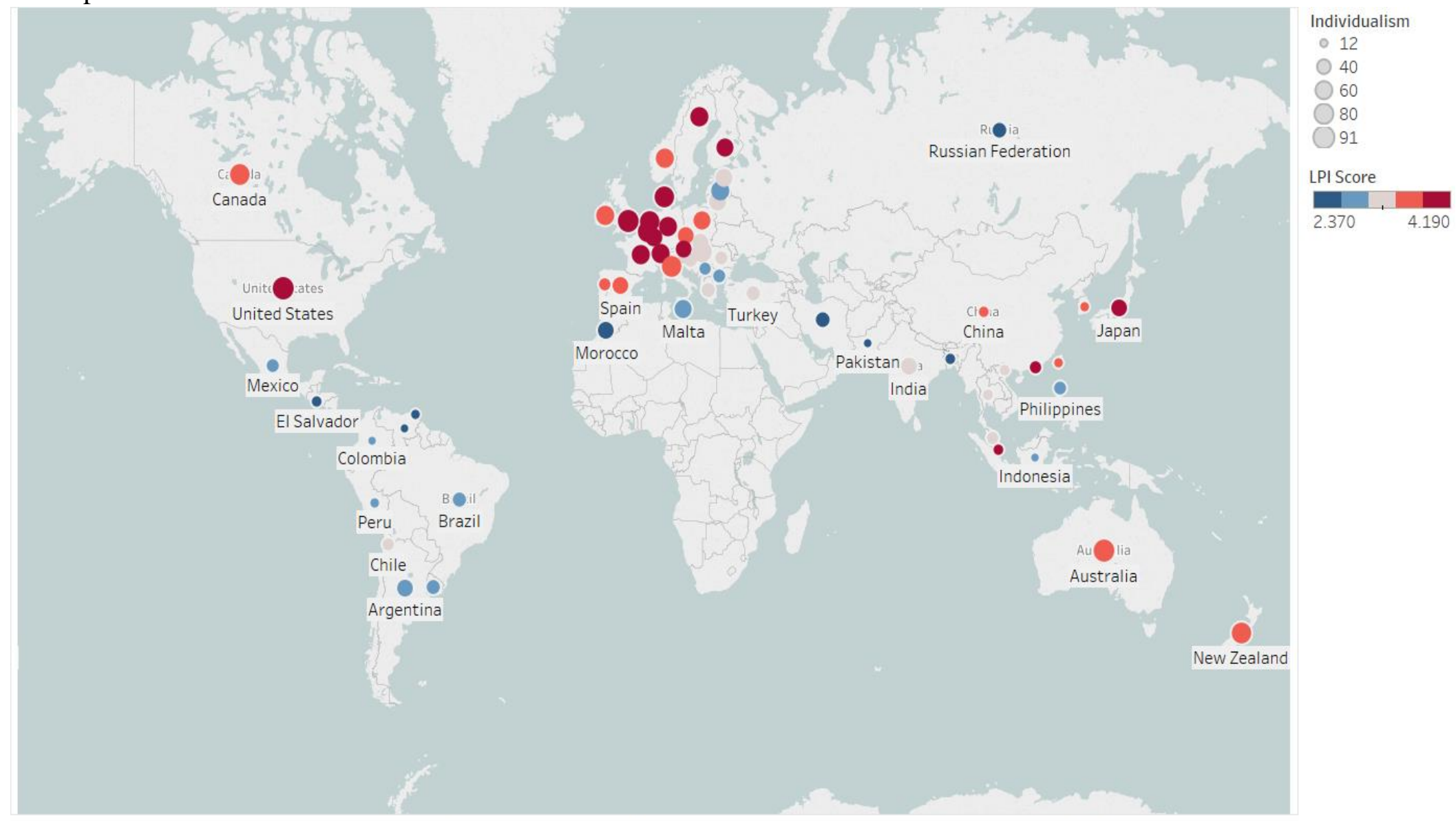

Map based on Longitude (generated) and Latitude (generated). Color shows sum of LPI Score. Size shows sum of Individualism. The marks are labeled by Country. Details are shown for Country. 
E. Map sized with Long Term Orientation

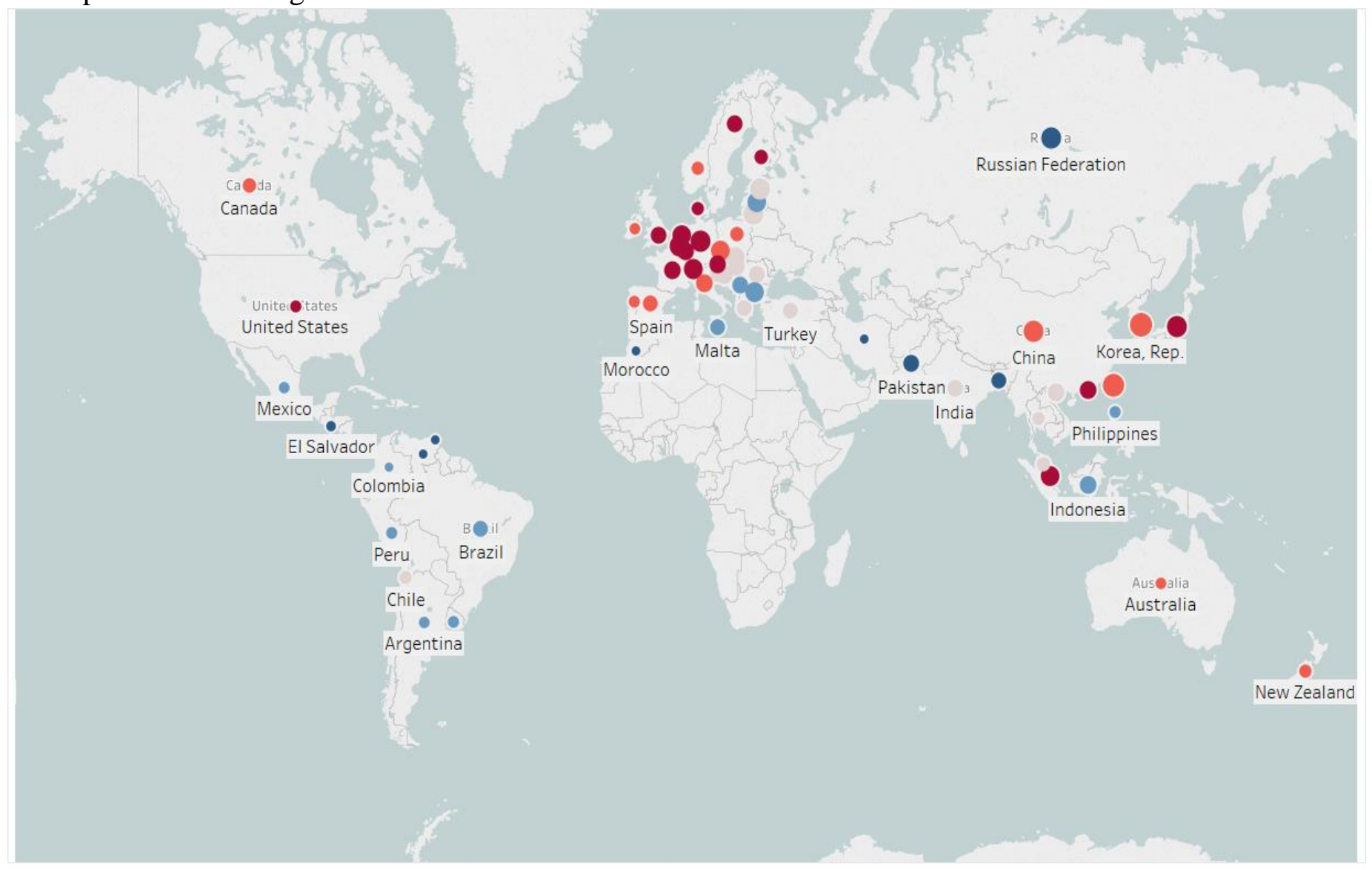

Long Term Orientation

- 12.59

40.00

60.00

80.00
100.00

LPI Score

$2.370 \quad 4.190$

Map based on Longitude (generated) and Latitude (generated). Color shows sum of LPI Score. Size shows sum of Long Term Orientation. The marks are labeled by Country. Details are shown for Country. 
F. Map sized with Uncertainty Avoidance

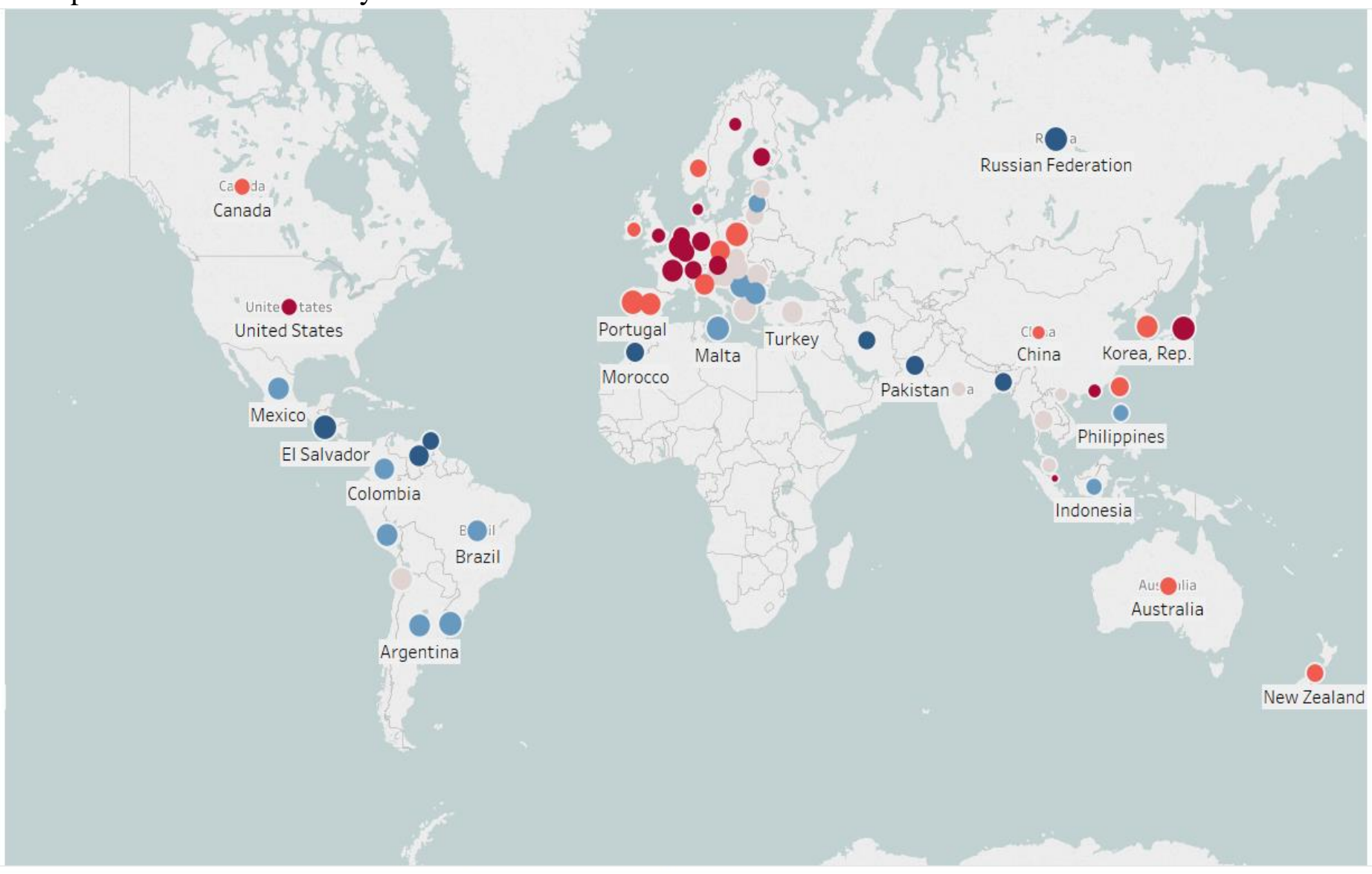

Map based on Longitude (generated) and Latitude (generated). Color shows sum of LPI Score. Size shows sum of Uncertainty Avoidance. The marks are labeled by Country Details are shown for Country. 